\title{
Self-assembly of amphiphilic peptides
}

\author{
Article
}

Accepted Version

Hamley, I. (2011) Self-assembly of amphiphilic peptides. Soft Matter, 7 (9). pp. 4122-4138. ISSN 1744-683X doi: https://doi.org/10.1039/c0sm01218a Available at https://centaur.reading.ac.uk/19780/

It is advisable to refer to the publisher's version if you intend to cite from the work. See Guidance on citing.

Published version at: http://dx.doi.org/10.1039/c0sm01218a

To link to this article DOI: http://dx.doi.org/10.1039/c0sm01218a

Publisher: Royal Society of Chemistry

All outputs in CentAUR are protected by Intellectual Property Rights law, including copyright law. Copyright and IPR is retained by the creators or other copyright holders. Terms and conditions for use of this material are defined in the End User Agreement.

\section{www.reading.ac.uk/centaur}

\section{CentAUR}

Central Archive at the University of Reading

Reading's research outputs online 


\section{Self-Assembly of Amphiphilic Peptides}

I.W.Hamley,*

Dept of Chemistry, University of Reading, Whiteknights, Reading, RG6 6AD, UK

For Soft Matter

* Author for correspondence. Also at Diamond Light Source, Harwell Science and Innovation Campus, Chilton, Didcot, Oxfordshire OX11 0DE, UK 


\begin{abstract}
The self-assembly of amphiphilic peptides is reviewed. The review covers surfactantlike peptides with amphiphilicity arising from the sequence of natural amino acids, and also peptide amphiphiles in which lipid chains are attached to hydrophilic peptide sequences containing charged residues. The influence of the secondary structure on the self-assembled structure and vice versa is discussed. For surfactant-like peptides structures including fibrils, nanotubes, micelles and vesicles have been reported. A particularly common motif for PAs is $\beta$-sheet based fibrils, although other structures have been observed. In these structures, the peptide epitope is presented at the surface of the nanostructure, providing remarkable bioactivity. Recent discoveries of potential, and actual, applications of these materials in biomedicine and bionanotechnology, are discussed.
\end{abstract}




\section{Introduction}

This Review focuses on recent developments resulting from studies on the selfassembly of amphiphilic peptides, and applications of these systems which appear particularly promising in bionanotechnology and biomedicine. We consider two main classes of amphiphilic peptides; these are (i) designed purely peptidic systems with amphiphilic properties arising from sequences of hydrophobic and hydrophilic (charged) residues, and (ii) peptides modified by attachment of hydrophobic lipid chains these are termed peptide amphiphiles (PAs). A distinction is made in this review between amphiphilic peptides and PAs, since PAs are a subset of the former but not vice versa.

The self-assembly of PAs has recently been reviewed. ${ }^{1}$ More generally, surfactantlike peptides and applications have been considered. ${ }^{2}$ Earlier reviews focussed specifically on PAs, ${ }^{3-5}$ and amphiphilic peptides more broadly ${ }^{6-8}$ However, there have been numerous developments in the subject even in the last few years since the publication of these articles. The purpose of the present Review is to provide a focussed tutorial-style update on the topic. The related topic of amphiphilic polymerpeptide conjugates (eg. attachment of hydrophobic peptides to hydrophilic PEG) is dealt with in numerous recent reviews on this topic. ${ }^{9-14}$

For convenience, in the following the lipid chain length in PAs is denoted $C_{n}$ where $n$ denotes the number of carbon atoms in the chain. The peptide is denoted with single letter abbreviation for the amino acids, with end group notation as given in the cited literature, i.e. where the end group is specified it is reported here, otherwise not (in 
most cases this would imply uncapped end groups). Table 1 summarizes the structure of the PAs and the nature of the studies discussed in this Review.

\section{Self-Assembly: Amphiphilic Peptides}

Zhang's groups pioneered studies on the self-assembly of model surfactant-like peptides (SLPs). These contain hydrophobic tails having four or more consecutive hydrophobic residues attached to a headgroup with two or more charged amino acids. ${ }^{7}$ Nanotube, or at least fibril (tube formation is not clear in all cases), formation was observed for $A_{6} D, V_{6} D, V_{6} D_{2}$ and $L_{6} D_{2}{ }^{15}$ and similar peptides containing $G$ instead of A as hydrophobic residue. ${ }^{16}$ In certain cases (eg. $\left.\mathrm{G}_{6} \mathrm{D}_{2}\right)$, vesicular structures were also reported. ${ }^{16}$ Fig. 1 illustrates a proposed mechanism of nanotube formation by $V_{6} D$ in which the nanotube comprises a peptide bilayer. ${ }^{15}$ The formation of branch points such as the three-way junction illustrated was also observed in TEM images. The adsorption of $\mathrm{V}_{6} \mathrm{~K}_{2}, \mathrm{~V}_{6} \mathrm{~K}$ and $\mathrm{V}_{3} \mathrm{~K}$ at the solid/liquid interface has been studied increased hydrophobicity led to a reduced critical aggregation concentration (cac) and an increase in adsorbed amount. ${ }^{17}$ Defective membrane structures were imaged for $\mathrm{V}_{6} \mathrm{~K}$ by AFM. The thickness was consistent with a peptide bilayer, and this could be used to immobilize DNA (via electrostatic interaction). SLPs containing basic amino acids were also studied and below the $\mathrm{pI}$ where the $\mathrm{K}$ or $\mathrm{H}$ is charged, self-assembled structures including nanotubes and vesicles were observed by TEM. ${ }^{18}$

The self-assembly of $\mathrm{Ac}-\mathrm{A}_{6} \mathrm{~K}-\mathrm{COOH}$ and $\mathrm{Ac}-\mathrm{A}_{6} \mathrm{D}-\mathrm{COOH}$ has been studied in particular detail - the cac has been determined (by dynamic light scattering) and nanostructures imaged by AFM. ${ }^{19}$ It was proposed that these were nanotubes, often exhibiting periodic bulging (these structures actually resemble twisted fibrils or tapes). 
Mixing of SLPs such as Ac- $\mathrm{A}_{6} \mathrm{~K}-\mathrm{NH}_{2}$ and $\mathrm{Ac}-\mathrm{A}_{6} \mathrm{D}-\mathrm{OH}$ has been investigated, in terms of the effect of mixture composition on the cac. ${ }^{20}$ A substantial decrease in cac was observed upon increasing $\mathrm{Ac}-\mathrm{A}_{6} \mathrm{~K}-\mathrm{NH}_{2}$ content in the mixture, and this was ascribed to a synergistic effect due to balancing of electrostatic interactions. The formation of self-assembled twisted fibril structures was observed for $A c-A_{6} D-O H$ alone under appropriate conditions and for certain mixtures of the peptides, above the cac. $^{20}$ Zhang's group have also developed the well known self-assembling peptide RADA-16I [Ac-(RADA) $)_{4}-\mathrm{CONH}_{2}$ ] which forms a fibrillar hydrogel that has great utility in stimulating cell growth and for tissue scaffolding. ${ }^{7,21,22}$ It has been commercialised as PuraMatrix, however as this is not a surfactant-like peptide further details are not provided here. The heptapeptide SLP Ac-GAVILRR-NH 2 has been shown to form donut-like ring structures in aqueous solution, and this was rationalised based on the cone-like structure of the amphiphilic peptide with two bulky charged arginine residues forming the headgroup. ${ }^{23}$

A comparative study of $\mathrm{I}_{6} \mathrm{~K}_{2}, \mathrm{~L}_{6} \mathrm{~K}_{2}$ and $\mathrm{V}_{6} \mathrm{~K}_{2}$ indicates that $\mathrm{I}_{6} \mathrm{~K}_{2}$ forms flat ribbon-like structures in aqueous salt solution (as imaged by electron microscopy and atomic force microscopy), correlated to the formation of $\beta$-sheets (probed by CD). ${ }^{24}$ In contrast, $\mathrm{L}_{6} \mathrm{~K}_{2}$ and $\mathrm{V}_{6} \mathrm{~K}_{2}$ self-assemble into rod-like fibrils, with CD suggesting random coil structures. ${ }^{24}$ These findings are unusual, in that even short fibrils are usually associated with ordered secondary structure (usually $\beta$-sheet). It has recently been pointed out that batch-to-batch variation (with concomitant purity variation) can affect the observed self-assembled morphology of this type of peptide, in particular $\mathrm{V}_{6} \mathrm{D}_{2}, \mathrm{~V}_{5} \mathrm{DVD}$ and $\mathrm{V}_{4} \mathrm{D}_{2} \mathrm{~V}_{2} .{ }^{25}$ Fibres, tapes and twisted ribbons were observed but not the nanotubes and vesicles reported previously by Zhang’s group. Circular dichroism 
(CD) and HPLC revealed $\beta$-sheet features for $V_{6} D_{2}$ and $A c-V_{6} D_{2}$. HPLC revealed the presence of significant fractions of impurities associated with the coupling reaction of hydrophobic residues in the peptide. ${ }^{25}$

The self-assembly properties as a function of hydrophobic tail chain length were investigated for $A_{3} K, A_{6} K$ and $A_{9} K{ }^{26}$ The cac was determined from conductivity measurements and surface tensiometry. Atomic force microscopy (AFM) was used to probe the presence, and morphology of aggregated structures. It was reported that $\mathrm{A}_{3} \mathrm{~K}$, which has no apparent detectable cac, forms stacked bilayers, $\mathrm{A}_{6} \mathrm{~K}$ forms nanofibres (actually, this system forms nanotubes, vide infra) and $\mathrm{A}_{9} \mathrm{~K}$ forms nanorods. Nanorods are distinguished from nanofibres by being short, and lacking flexibility. The $c a c$ was found to be lower for $\mathrm{A}_{9} \mathrm{~K}$ than $\mathrm{A}_{6} \mathrm{~K}$, as expected. ${ }^{26}$ The amphiphilic peptides $\mathrm{A}_{6} \mathrm{~K}$ and $\mathrm{A}_{9} \mathrm{~K}$ show antibacterial properties against Gramnegative E. coli and Gram-positive $S$. aureus strains, while peptide $\mathrm{A}_{3} \mathrm{~K}$ showed almost no activity. ${ }^{27}$ The extent of antibacterial activity was correlated to the size of the hydrophobic unit, which influences the self-assembly of the peptides - only $A_{6} \mathrm{~K}$ and $\mathrm{A}_{9} \mathrm{~K}$ formed well-defined superstructures, these being long fibril-like structures and short nanorods respectively. The mode of antimicrobial action was proposed to be membrane permeation. ${ }^{27}$ It has recently been shown that $\mathrm{NH}_{2}-\mathrm{A}_{6} \mathrm{~K}-\mathrm{COOH}$ selfassembles into nanotubes (Fig.2), ${ }^{28}$ with a low dispersity in tube wall thickness $(<1$ $\mathrm{nm}$ ) which might correspond to single wall peptide nanotubes. ${ }^{28,29}$ A structural model for the peptide packing motif, based on results from X-ray diffraction experiments was also proposed (Fig.2). ${ }^{29}$ 
By mixing these SLPs with lipids, it is possible to control the curvature of the lipid membrane and hence the stability of structures such as bicontinuous cubic phases. This was specifically investigated in terms of the stability of the Pn3m phase formed by monoolein in water. ${ }^{30}$

Deming and coworkers have developed amphiphilic copolypeptides such as $\mathrm{K}_{m} \mathrm{~L}_{\mathrm{n}}$ or $\mathrm{K}_{\mathrm{m}} \mathrm{V}_{\mathrm{n}}$ where $\mathrm{m}$ and $\mathrm{n}$ are in the range of tens and hundreds, depending on the copolymer. $^{31,32}$ They studied their self-assembly properties such as hydrogelation ${ }^{32,33}$, vesicle formation ${ }^{34-36}$ or their use in templating structures in silica using $\mathrm{C}_{m} \mathrm{~L}_{n}$ copolypeptides. ${ }^{37,38}$ Although these systems may be considered "giant amphiphiles”, as this work concerns block copolymeric peptides, a detailed discussion is outside the scope of this review. Many other reviews on this subject are available. ${ }^{11,12,39}$

Two amphiphilic peptides produced by recombinant DNA techniques, Ac$\mathrm{A}_{2} \mathrm{~V}_{2} \mathrm{~L}_{3} \mathrm{WG}_{2}-\mathrm{COOH}$ and $\mathrm{Ac}-\mathrm{A}_{2} \mathrm{~V}_{2} \mathrm{~L}_{3} \mathrm{WG}_{7}-\mathrm{COOH}$ were shown to self-assemble into vesicles with relatively low polydispersity in aqueous solution, above a measured critical aggregation concentration. ${ }^{40}$ The formation of vesicles was rationalised based on the tapered shape of the molecules, with increasingly bulky amino acid side groups towards the hydrophilic domain. The encapsulation of the model water-soluble fluorescent molecule calcein was demonstrated.

The aggregation of the naturally occurring surface-active lipopeptide surfactin at airwater and hydrophobic solid-water interfaces has been studied by neutron reflectivity. ${ }^{41}$ It was found to form a ball-like structure similar to a hydrophobic nanoparticle solubilised by charge at the air-water interface. This is an interesting 
distinct class of PA comprising a cylic heptapeptide headgroup attached to a $\mathrm{C}_{10}\left(\mathrm{CH}_{3}\right)_{2}$ lipid. There are few other reports, to our knowledge, on biomimetic or de novo designed PAs based on cyclic peptides.

Amphiphilic peptides can be used to produce peptide particles based on the saltinduced aggregation of peptides forming micelles with a hydrophobic core and cationic corona. ${ }^{42}$ The peptides comprise hydrophilic lysines and hydrophobicW ${ }^{\mathrm{D}} \mathrm{L}$ repeats (inspired by a sequence from Gramicidin A). The size of the peptide particles depended on the position of the counterions in the Hofmeister series. By neutralizing the lysines by acetylation, it was possible to drive self-assembly into peptide beads which were produced via solvent exchange process. The acetylated peptides are too hydrophobic to dissolve in water and so ethanol-water solvent exchange was used. ${ }^{42}$

\section{Self-Assembly: $\beta$-sheet forming PA systems}

In a pioneering series of papers, Stupp’s group has elucidated the principles of selfassembly of PAs into $\beta$-sheet containing nanofibrils. Diverse applications of these systems in bionanotechnology are discussed further in section 5 of this review. Figure 3 shows a representative PA highlighting the structuring motifs incorporated, along with a representation of the nanofibril and SEM and TEM image of nanofibrils. ${ }^{5}$ Hydrogelation of PA fibril networks can be induced in several ways, such as control of $\mathrm{pH}^{43}$ or addition of divalent salts. ${ }^{43,44}$ The rheological properties of PA hydrogels based on fibrillar networks have been probed in the presence of $\mathrm{CaCl}_{2}$ or $\mathrm{HCl}^{44}$ The gels in $\mathrm{CaCl}_{2}$ have stronger intra- and inter-fibrillar crosslinks due to calcium ion- 
mediated ion bridge formation. To investgiate the role of different components of the peptide sequence, and lipid chain length, in a series of homologous PAs on the selfassembled structure, a series of PAs with varying sequence and total net charge were studied. ${ }^{43}$ Self-assembly into fibrils could be reversibly induced by control of $\mathrm{pH}$ (Fig.4). In addition, reversible covalent capture of nanofibrils by oxidative crosslinking of cysteine residues contained in many of the PAs studied was also demonstrated (Fig.4). In more recent work on a series of PAs containing $V_{m} A_{m} E_{3}$ repeats, ${ }^{45}$ the influence of hydrogen bond alignment on fibrillar gel stiffness was probed by shear rheometry. The extent of hydrogen bond alignment was deduced by comparing transmission FTIR with polarization-modulation infrared absorption spectroscopy (grazing mode on the sample surface). The fibrils were imaged by cryoTEM, and CD was used to measure the level of twisting and disorder of the $\beta$-sheets. Increasing the number or fraction of valine residues was found to increase the stiffness of fibrils, whereas alanines tended to reduce it. This was related to the extent of hydrogen bond alignment, and the positioning of $\beta$-sheet forming residues near the hydrophobic core of the nanofibrils. ${ }^{45}$ Pyrene and tryptophan fluorescence experiments have been used to probe the aqueous environment within PA selfassembled structures. ${ }^{46}$ These studies indicate a high degree of solvation in the interior. Stern-Volmer quenching constants and the fractional accessibility (of covalently bound pyrene) were found to increase as the choromophore is placed closer to the aggregate interior. Uptake of chromophore from solution was evidenced by solubilisation of free pyrene, and this points to the use of PAs to sequester hydrophobic organic molecules congruent with the presentation of bioactive motifs on the fibril surface. ${ }^{46}$ 
Coassembly of PAs with opposite charge within the peptide sequence has been investigated. ${ }^{47}$ Mixed self-assembly occurred due to electrostatic interaction since bundles of fibrils of oppositely charged PAs were not observed. Similarly, coassembly of PAs with opposite charge on the termini leads to structures with enhanced stability compared to those comprising one type of PA molecule only. ${ }^{48}$ Reverse PAs containing free $\mathrm{N}$ termini were prepared via use of an unnatural amino acid modified with a fatty acid chain and these were mixed with conventional PAs containing free C termini. Stupp’s group also described the synthesis and aqueous self-assembly (info fibrils) of "bola-amphiphiles" (molecule containing two hydrophilic headgroups linked by a hydrophobic spacer). ${ }^{49}$ The formation of macroscopic membranes at the interface between two liquids containing aqueous solutions of PA and hyaluronic acid (HA) respectively, has recently been described. ${ }^{50}$ In a remarkable discovery, it was found that macroscopic sacs or membanes can be produced - the membranes can be shaped in moulds, or drawn into strings. The membranes are proposed to comprise fibrils of the positively charged PAs, around which negatively charged HA polymer chains are decorated. Possible applications of the sacs/membranes in biotechnology such as cell encapsulation or barrier materials were proposed.

Molecular dynamics computer simulations have shed light on the self-assembly process of PAs, leading to a "phase diagram” parameterized in terms of the hydrogen bonding strength versus hydrophobic attraction strength. ${ }^{51}$ The phase diagram contains regions corresponding to long cylindrical fibrils, micelles, single $\beta$-sheets, stacks of $\beta$-sheets and amorphous aggregates. 
The formation of tape-like structures termed "nanobelts” (Fig.5a-c) has recently been described. ${ }^{52}$ The de novo designed PAs such as $\mathrm{C}_{16} \mathrm{O}-\mathrm{VEVE}$ form strands containing charged and hydrophobic faces. This leads to the formation of tapes containing PA bilayers parallel to the flat surface of the tapes. The tapes present peptide epitopes (within $\beta$-sheets) at the surfaces (Fig.5d). The important role of electrostatic interactions is highlighted by the ability to reversibly break tapes into grooved tapes (Fig.5d). The unravelling of the tapes into twisted fibrils can be observed in dilute solution (Fig.5e,f). Twisted nanoribbons were also observed for the $\mathrm{PA}_{16} \mathrm{O}$ VEVEGRGD containing the RGD cell adhesion motif. ${ }^{52}$ The mechanism of the transformation from twisted ribbons into helical ribbons for a PA containing phenylalanine repeats has been elucidated by state-of-the-art cryo-TEM experiments. ${ }^{53} \mathrm{~A}$ sample in which the $\mathrm{F}_{3}$ repeat was replaced with $\mathrm{A}_{3}$ formed cylindrical fibrils, pointing to the importance of the F residues which undergo $\pi-\pi$ stacking interactions in driving the self-assembly into ribbons. The transition in the arrangement of the $\beta$-strands within the aggregates is related to the most stable packing motif of the PAs. ${ }^{45}$

The self-assembly of branched PAs and their use to present the RGDS cell adhesion motif has been described. ${ }^{54}$ Self-suporting fibrillar hydrogels were observed in the presence of physiological fluids such as synovial fluid and DNA. Tryptophan fluorescence experiments indicated that there is greater mobility in the aggregates of branched PAs than linear analogues. More information on the use of RGD(S) functionalized PAs in stimulating cell growth or adhesion, relevant for example to tissue engineering, is discussed in Section 5.1. 
In another proof-of-concept demonstration, Stupp’s group showed that PA nanofibrils can be decorated with receptors to template the deposition of target lipophilic gold nanoparticles. ${ }^{55}$ The PA fibrils were prepared by co-assembly with PAs containing thymine moiety. Lipophilic gold nanoparticles were functionalized with the complementary DAP (diaminopyridine) moiety, which drives binding with the nanofibrils when the nanoparticles are mixed in solution. Further details on the use of PAs in biomineralization are provided in section $5.3 .^{55}$

An X-ray radiation- induced disorder-order transition was observed for $\mathrm{PA} \mathrm{C}_{16}-\mathrm{A}_{6} \mathrm{E}_{3}$ (and related PAs). ${ }^{56}$ In dilute solution, this system underwent a transition from an isotropic phase to a hexagonal phase upon exposure to synchrotron X-rays, i.e. twodimensional liquid crystal ordering of the fibrils was induced (Fig.6a). The transition was found to be reversible, and was ascribed to X-ray induced charging of the fibrils due to reversible ionization of the $\mathrm{COOH}$ groups. The role of electrostatic interactions was confirmed by salt screening experiments. A mechanism for templated growth of filament bundles was proposed (Fig.6b).

It has recently been discovered that aligned threads of PAs can be created by injecting noodle-like strings of PA solution (after heat treatment) from a pipette into a saline solution or dragging a thread of PA solution across a film of $\mathrm{CaCl}_{2}$ (Fig.7a-c). ${ }^{57}$ The strings contain bundles of highly aligned fibrils. The heat treatment comprises heating PAs to above the lipid chain melting temperature (to $80{ }^{\circ} \mathrm{C}$ ), cooling back to $25{ }^{\circ} \mathrm{C}$ and addition of $\mathrm{CaCl}_{2}$ and this leads to the formation of birefringent gels (Fig.7d). This thermal pathway leads to a lamellar plaque structure, which ruptures into bundles 
of nanofibres on cooling (Fig.7e,f). An analytical model for this was presented. The extruded PA strings could be used to preferentially align encapsulated cells. ${ }^{57}$

The influence of alkyl chain length on the self-assembly in aqueous solution of a designed amyloid forming peptide Ac-KTVIIE- $\mathrm{NH}_{2}{ }^{58}$ was investigated, with a specific focus on thermal stability as probed by CD and TEM. ${ }^{59}$ The stability of $\beta$ sheet self-assemblies against dilution and temperature was enhanced for $\mathrm{C}_{12}, \mathrm{C}_{14}$ and $\mathrm{C}_{16}$ chains, in contrast to PAs with shorter alkyl chain lengths $\left(\mathrm{C}_{6}\right.$ and $\left.\mathrm{C}_{8}\right)$. In a development of this work, the influence of C-terminally attached hydrophilic PEG on the self-assembly was examined. ${ }^{60}$ A PEG-peptide was shown not to self-assemble, as expected due to the high hydrophilicity. However, to study the balance between hydrophilic destabilization and hydrophobic stabilization, PEG was also C-terminally attached in a PA (containing the same KTVIIE peptide sequence). By linking the $\mathrm{C}_{18}$ alkyl chain via a nitrobenzyl group it was possible to cleave the hydrophobic tail using UV radiation leading to disruption of $\beta$-sheet structure and hence destruction of fibrillar structures. ${ }^{60}$ In a previous study by this group of PAs containing the nonapeptide GANPNAAG based on a protein from a malaria parasite protein, distinct self-assembled motifs were identified depending on alkyl chain length. ${ }^{61} \mathrm{CD}$ revealed that $\mathrm{C}_{6}, \mathrm{C}_{10}$ and $\mathrm{C}_{12}$ derivatives adopted random coil conformations, independent of temperature whereas $C_{14}$ and $C_{16}$ derivatives underwent a transition from $\beta$-sheet at room temperature to random coil at high temperature. The transition temperature increased from $\mathrm{C}_{14}$ to $\mathrm{C}_{16}$ (but not for $\mathrm{C}_{18}$ ). ${ }^{61}$ These results point to the delicate balance between hydrophobicity and electrostatic interactions in thermally stabilizing self-assembled PA structures in aqueous solution. 
The van Hest group has investigated the polymerization of PAs containing diacetylene units. ${ }^{62}$ The influence of the placement of the diacetylene moiety (Fig.8a) on the chromatic properties (UV/vis absorption spectrum) was examined, this being influenced by conjugation length of the polydiacetylenes and the packing of groups either side of the diacetylene units. ${ }^{62}$ One of these PAs has been used to demonstrate spatially selective polymerization (mechanism shown in Fig.8b) using polarization holography on films in which fibrils were aligned in the presence of a strong magnetic field. ${ }^{63}$ The magnetic alignment of this system was studied in prior work, in which conditions to achieve alignment were examined in more detail. ${ }^{64}$

The influence of amino acid sequence on the self-assembly of designed PAs containing $\mathrm{C}_{16}$ chains and dodecapeptides with variable position of $\mathrm{A}$ residue within a hydrophobic sequence of $\mathrm{N}$-terminal $\mathrm{G}$ residues and a $\mathrm{C}$ terminal charged ERGDS sequence has been examined. ${ }^{65}$ Shifts in the position of the alanine residue affect the hydrogen-bonding pattern and packing of the peptides leading to differences in secondary structure. The presence of the chiral alanine residue simplifies interpretation of the CD spectra. It was found that four core hydrogen bonds are required to form $\beta$-sheet structures, whereas if the A residue is located in the core region, this is disrupted and a polyproline II -type secondary structure is adopted instead. This paper also describes the use of FTIR to deduce information on the orientation of the $\beta$-sheet forming PAs with respect to the fibril axis, through comparison of transmission FTIR on a bulk sample and ATR-FTIR on a film. This led to the conclusion that the PA molecules are arranged radially, perpendicular to the fibril axis (Fig.9) ${ }^{65}$ Hartgerink’s group has also developed PAs to form nanofibers to catalyse the formation of silica nanotubes. ${ }^{66}$ The PAs comprise $\mathrm{C}_{16} \mathrm{O}$ chains attached 
to $\mathrm{A}_{\mathrm{m}} \mathrm{X}_{4}$ peptides where $\mathrm{X}$ is $\mathrm{K}, \mathrm{H}$ or $\mathrm{E}$ and these were used to template the polymerization of tetraethoxysilane (TEOS).

Lipidation to produce PAs can change the arrangement of secondary structure elements (in addition to influencing the secondary structure itself). For example, it has been demonstrated using solid state NMR techniques that attachment of an octanoyl chain drives the formation of parallel $\beta$-sheets in a PA containing $A \beta(16-22)[A \beta$ denotes the amyloid $\beta$ peptide] whereas the native heptapeptide forms antiparallel $\beta$ sheets. ${ }^{67}$ The amphiphilicity dominates the self-assembly process as the hydrophobic residues are shielded from the aqueous environment, in contrast to the preponderant intermolecular hydrogen bonding and electrostatic interactions for the native peptide.

It is possible to prepare monolayers, and measure the surface-pressure area isotherms of PAs at the air/water interface by Langmuir-Blodgett film techniques. ${ }^{68}$ This was investigated in detail for a series of dipalmitoyl PAs. At high surface pressure, it is possible to compress the PAs such that the chains become fully extended. The surface pressure -area characteristics are determined by the peptide head group length and its sequence. ${ }^{68}$ The formation of ordered monolayers comprising $\beta$-sheet lipopeptides at the air/water interface has been reported. ${ }^{69}$ The structural model was largely based on grazing-incidence X-ray diffraction complemented by Brewster angle microscopy and surface pressure/area isotherm measurements, while secondary structure was probed by CD and FTIR.

A sequence from the amyloid $\beta$ (A $\beta$ ) peptide that favours $\alpha$-helical secondary structure was incorporated into a PA with a $\mathrm{C}_{12}$ chain. ${ }^{70}$ The critical micelle 
concentration $(\mathrm{cmc})$ was determined at two $\mathrm{pH}$ values. At $\mathrm{pH} 10, \beta$-sheet features were observed by CD showing that conjugation of the peptide to a lipid chain favours $\beta$-sheet formation under conditions where the charge on the peptide is reduced (compared to $\mathrm{pH}$ 3), enabling hydrogen bonding to occur. Fibrillisation was observed by AFM including the formation of tape-like fibrils at sufficiently high concentration. The formation of twisted nanoribbons was related to the formation of $\beta$-sheets at $\mathrm{pH}$ $10 .^{70}$ In related work, the self-assembly of PAs containing the amyloidogenic amylin(20-29) sequence was investigated. ${ }^{71}$ Addition of a single $\beta$-aminoethane sulfonamide moiety was found to distupr amyloid fibril formation. Alkylation of the sulphonamide restored fibrillisation and led to hydrogelation. Variation of alkyl chain length influenced the self-assembled structure which varied from helical and twisted ribbons through to entangled fibres. CD did not provide clear information on secondary structure for all of the PAs. ${ }^{71}$

\section{Self-Assembly: $\alpha$-helical PA systems}

As discussed in the preceding section, attachment of alkyl chains can stabilize secondary structure in PAs. This has also been demonstrated for $\alpha$-helical peptides. In a series of papers, Fields and coworkers have investigated the lipid-induced stabilization of collagen-based peptides forming helical secondary structure. ${ }^{72-74}$ Initial work established that a series of dialkyl chain collagen-based PAs formed polypro II triple helical structures, and that lipidation enhanced the thermal stability of the helical conformation, compared to the peptides alone. ${ }^{72}$ For a series of PAs with varying alkyl chain length (from $\mathrm{C}_{6}$ to $\mathrm{C}_{16}$ monoalkyl, even chain length and $\left(\mathrm{C}_{12}\right)_{2}$ dialkyl), the helix-coil "melting temperature" was located by CD. It was found to 
increase with alkyl chain length, pointing the stabilization of the collagen-like triple helical conformation. This was also monitored by ${ }^{1} \mathrm{H}$ NMR spectroscopy (specifically probing the environment of the $\mathrm{W}$ residue). ${ }^{73}$ Forns et al. studied PAs containing a 16residue peptide containing a heptad repeat designed to form coiled coil structures and also a 39 residue peptide containing a collagen-based sequence forming a triple helical structure. ${ }^{74}$ Addition of $\mathrm{C}_{6}$ or $\mathrm{C}_{16}$ chains to the 16 residue peptide induced $\alpha$ helix formation, absent for the peptide on its own. The thermal stability of the $\alpha$-helix was greater for the $\mathrm{C}_{16}$ PA. Similar findings in terms of enhanced thermal stability were reported for the 39 residue peptide (which however does form helical structure without the attached lipid chain).

Wormlike micelle formation has been noted for a $\mathrm{C}_{16}$ PA containing a designed peptide $\mathrm{WA}_{4} \mathrm{KA}_{4} \mathrm{KA}_{4} \mathrm{KA}$ with a propensity to form $\alpha$-helices. ${ }^{75}$ The initially formed morphology was spherical micelles and the secondary structure comprised a mixture of $\alpha$-helical and random coil structures. The structure transformed into wormlike micelles over a time period $\sim$ days, accompanied by a transition to a $\beta$-sheet secondary structure.

The self-assembly of PAs comprising pentapeptides containing the RGD cell adhesion motif attached to $\mathrm{C}_{11}$ or $\mathrm{C}_{12}$ alkyl chains, or an Fmoc moiety, has been examined. TEM suggested a variety of structures (micelles, vesicles or $\mathrm{pH}$ ) depending on the peptide sequence and $\mathrm{pH}^{76} \mathrm{CD}$ suggested contribution from $\alpha$-helical structure, especially at higher $\mathrm{pH}$. 
A PA containing a DNA-binding motif along with a coiled-coil inducing heptapeptide sequence has been shown to self-assemble into helical ribbons and tubules. ${ }^{77} \mathrm{CD}$ indicated an $\alpha$-helical conformation for the peptide. Addition of co-surfactant (SDS) led to the formation of spherical micelles. The subject of gene delivery by DNA condensation is discussed further in section 5.2.

\section{Applications}

\subsection{Tissue Scaffolds}

One of the most common motifs for cell adhesion studies within the field of PAs, and more broadly is the integrin recognition motif $\mathrm{RGD}(\mathrm{S})$ from fibronectin. In pioneering work, Tirrell’s group attached linear RGD (via amino or carboxyl units) to dialkyl lipid chains, and also prepared a conjugate containing looped RGDS (connected via linkers to dialkyl chains on each side). ${ }^{78}$ Concentration-dependent spreading of melanoma and endothelial cells was observed on Langmuir-Blodgett films of the looped PA, whereas indiscriminate spreading was observed for the carboxyl-coupled PA, and no spreading was found for the amino-attached PA. Adhesion was not observed using control PAs containing looped RGE, and it was also blocked for the looped RGD PA by antibody inhibition of integrin receptors. ${ }^{78}$ Prior to this, Oku et al. had investigated RGD-based PAs in a study on liposomes for cancer metathesis. ${ }^{79}$ The PAs were found to inhibit spontaneous metastasization.

The incorporation of the RGD adhesion motif in PAs was also discussed by MarchiArtzner et al. ${ }^{80}$ They synthesized several di-alkyl lipid chain PAs containing the cyclic[RGDF(K)] [(K) denotes attachment of the cyclic peptide through the lysine $\varepsilon^{-}$ amino group] peptide and studied adhesion to integrins $\left(\alpha_{\mathrm{IIb}} \beta_{3}\right.$ from human blood 
platelets) tethered to glass substrates. Fluorescently labelled PAs were incorporated into vesicles and the adhesion of the vesicles was investigated by interference microscopy and fluorescence microcopy. These results shed light on the selective interaction of RGD-functionalized giant vesicles with endothelial cells. The adhesion and spreading of these cells, and also of human umbilical cord on solids functionalized with the RGD PAs was demonstrated. ${ }^{81}$ The spreading and adhesion of endothelial cells in multiwall plates coated with a PA has been investigated. ${ }^{82}$ The PA incorporated a 16-residue $\alpha$-helical promoting domain and a sequence from the SPARC cellular matrix protein associated with collagen. The 119-122 sequence from SPARC is known to stimulate endothelial cell proliferation and angiogenesis. The self-assembly of the PAs was also investigated - CD revealed a predominantly $\alpha$ helical structure, and an increase in thermal stability with increasing alkyl chain length. The best cell adhesion properties were obtained by mixing the SPARC-based PAs with a PA incorporating the $\alpha 2 \beta 1$ integrin binding site from type I collagen and a pseudolipid. $^{82}$

Hartgerink's group have investigated the viscoelastic properties of PA fibrillar hydrogels, induced in the presence of divalent (calcium) ions. ${ }^{83}$ The PAs contained the RGDS cell adhesion motif, as well as a proteolytically degradable sequence specific for MMP2, GTAGLIGQ. They also demonstrated the encapsulation of neural cells within the hydrogels, and the degradation of the networks using collagenase.

Stupp’s group have made important breakthroughs in demonstrating potential applications of PAs in regenerative medicine. For example, the selective differentiation of neural progenitor cells using PA nanofibrils containing peptides 
incorporating the IKVAV cell adhesion motif from laminin has been established. ${ }^{84}$ The cells were encapsulated within a three-dimensional fibrillar gel and rapidly differentiated into neurons, in contrast to control peptides, for example non-lipidated laminin or poly(D-lysine). The same PA was shown to be effective in treating spinal cord injury using a mouse model. ${ }^{85}$ The self-assembling nanofibers inhibited glial scar formation and to promote axon elongation.

Stupp and coworkers have shown that PAs presenting the RGDS cell adhesion motif can be used as scaffolds for therapeutic delivery of bone marrow derived stem and progenitor cells. ${ }^{86}$ Optimal cell adhesion was found for a binary PA system comprising $10 \mathrm{wt} \%$ RGDS-based PAs and $90 \mathrm{wt} \% \mathrm{C}_{16}-\mathrm{V}_{3} \mathrm{~A}_{3} \mathrm{E}_{3}$ charged diluent (“filler”) PA molecules. A bioactive peptide mixed with a filler peptide has also been applied to cartilage regeneration. ${ }^{87}$ The bioactive peptide incorporates a transforming growth factor $\beta 1$ (TGF- $\beta 1$ ) binding domain. The fibrillar gel incorporating the TGF$\beta 1$ binding domain released TGF- $\beta 1$ more slowly than a gel prepared from the nonbioactive PA alone. The chondrogenic differentiation of human mesenchymal stem cells was shown, as was the regeneration of articular cartilage in a rabbit model. ${ }^{87}$ In a further development relevant to future tissue bioengineering, Stupp’s group have shown that angiogenesis, i.e. the production of new blood vessels, can be stimulated using PAs contain a heparin-binding sequence that self-assemble into nanofibrils that present the bioactive motif at their surface. ${ }^{88}$

A hierarchical method to align human mesenchymal stem cells based on a polymerizable PA system has been reported. ${ }^{89}$ The PAs contain diacetylene units in the lipid tails which undergo UV-induced polymerization (cf. Fig.8). The functional 
peptide contains the RGDS cell adhesion motif. Alignment was induced by soft lithography techniques, i.e. compression of the PA solution in channels using PDMS moulds in the presence of base which neutralizes charge and causes self-assembly of the PAs which, aligned by flow fields on compression, were then polymerized by exposure to UV irradiation. The use of soft lithography without cross-linking of PAs as an alignment tool had been demonstrated earlier by the Stupp group. ${ }^{90}$ Solvent evaporation within the elastomeric stamp lead to orientation of nanofibers parallel to the channels, and it was suggested that this might occur via a lyotropic liquid crystalline phase.

Matrixyl is the tradename for the commercial PA, $\mathrm{C}_{16}$-KTTKS which was patented by Sederma S.A. (France) for use in personal care and cosmetic applications in particular for treatment of visible signs of aging such as wrinkles. ${ }^{91}$ This is actually the only PA in use in the market at present, to our knowledge. A number of reports on its application in cosmetics in anti-wrinkle treatments are available in the open literature. ${ }^{92-95}$ PAs $\mathrm{C}_{16}-\mathrm{GHK}$ and $\mathrm{C}_{16}$-GQPR are of interest for similar applications, and a method to assay PA content in anti-wrinkle creams based on LC/MS has been reported. ${ }^{93}$ Our group has recently investigated the self-assembly of this system in detail and we have shown that $\mathrm{C}_{16}$-KTTKS forms large fibrillar superstructures, with lengths extending to at least 10-100 mm (Fig.10a,b). ${ }^{96}$ These fibrils are based on nanotapes (with nanoscale width and thickness), the structure of which was elucidated by SAXS and shown to comprise PA bilayers parallel to the tape surface (Fig.10c). Understanding the self-assembled motif is expected to be important in controlling the formulation and hence collagen-stimulating activities (this is currently under investigation by our group). 
Kokkoli and coworkers have been exploring the use of PAs containing the GRGDSP cell adhesion motif and the PHSRN synergy motif in the development of hydrogels for tissue scaffolding. ${ }^{97-101}$ They investigated the binding of PAs containing one or both of these motifs to $\alpha 5 \beta 1$ integrins by AFM. ${ }^{97,} 98$ The PAs formed LangmuirBlodgett monolayers (the surface pressure/area characteristics of which could also be controlled) deposited onto mica and the integrins were attached to AFM tips by immobilization using antibodies. The recognition of the immobilized receptor was significantly enhanced for the PAs presenting both GRDSP and PHSRP sites. ${ }^{97}$ Mixing a PEG lipid (DSPE-PEG) with PAs containing both motifs was found to facilitate adhesion, an observation ascribed to enhanced presentation of PHSRN due to enhanced packing of the peptide headgroups. ${ }^{98}$ The influence of linker groups (before the PHSRN group and between this and the RGDSP domain) has been examined in a similar manner - leading to the conclusion that a short spacer is optimal. ${ }^{100}$ This group have recently optimised the design of the PA [C $16^{-}$ $\mathrm{G}_{3} \mathrm{~S}_{2} \mathrm{PHSRN}(\mathrm{SG})_{5} \mathrm{RGDSP}$ ] to incorporate a linker that favours $\beta$-sheet formation as well as a single alkyl chain. ${ }^{101}$ These features are shown to enable self-assembly into nanofibrils, and hydrogelation occurs for sufficiently concentrated samples. The adhesion and proliferation of HUVEC cells were studied, as well as fibronectin production (fibronectin being an important part of the ECM). This peptide was superior to peptides studied earlier by this group such as the closely related peptide $\mathrm{C}_{16}-\mathrm{KSSPHSRN}(\mathrm{SG})_{5} \mathrm{RGDSP}^{99}$ due to the inclusion of the $\mathrm{G}_{3} \mathrm{~S}_{2}$ linker unit. The performance of these materials was good in comparison to other hydrogels, including those containing PEG and commercially available systems such as PuraMatrix based on Ac-(RADA) $)_{4}-\mathrm{CONH}_{2}$ discussed in section 2 above. ${ }^{101}$ 


\subsection{Delivery and Cell Internalization}

Transport of hydrophobic drugs or other actives into cells remains an important challenge in biomedicine. A PA-based nanocarrier system with the potential to become internalized wihin the cell has been researched. ${ }^{102}$ The PA comprises the tandem dimer (LRKLRKRLLR) ${ }_{2}$ that contains binding sites for the low-density lipoprotein receptor and for cell-surface heparin sulphate proteglycans. The peptide was conjugated to a dipalmitoyl lipid tail. The cmc was found to be extremely low and vesicles were prepared by mixing with a conventional lipid. Internalization of fluorescently labelled PA within endothelial cells was imaged. ${ }^{102}$

The mechanism of internalization of a PA comprising a pro-apoptotic peptide derived from the p53 tumor suppressor protein attached to a $\mathrm{C}_{16}$ lipid chain has been investigated via fluorescence mechanisms using mixtures of unlabelled and rhodamine-labelled PAs. ${ }^{103}$ Self-assembly into rod-shaped micelles was reported. Based on analysis of self-quenching of tryptophan-dansyl fluorescence (FRET), internalization into model liposomes was found to occur in the form of monomers rather than micelles. It was also concluded that attachment of the $\mathrm{C}_{16}$ chain led to enhanced uptake into cells (using an osteosarcoma cell line) compared to the unmodified peptide (Fig.11). ${ }^{103}$

Yang's group has investigated the use of amphiphilic peptides containing cationic peptide sequences for applications in gene delivery. ${ }^{104-106}$ Cholesterol-conjugated $\mathrm{H}_{5} \mathrm{R}_{10}$ and $\mathrm{H}_{10} \mathrm{R}_{10}$ were shown to self-assemble into cationic micelles, leading to an increase in localized charge (compared to the molecules without attached cholesterol) 
and an increase in DNA binding. ${ }^{106}$ Gene expression, probed using a luciferase reporter model, into Hep62 and HEK293 cells was demonstrated, with an enhancement in efficiency for the peptide containing ten histidine residues. The luciferase expression was assayed as a function of N/P [nitrogen/phosphate] ratio (which influences micelle size and zeta potential). ${ }^{104}$ In a parallel study, $\mathrm{A}_{12} \mathrm{H}_{5} \mathrm{~K}_{10}$ and $\mathrm{A}_{12} \mathrm{H}_{5} \mathrm{~K}_{15}$ were investigated. ${ }^{105}$ The cytotoxicity profile (using HEK293, HepG2 and 4T1 cell lines) was favorable compared to polyethyleneimine (PEI), widely used as a synthetic DNA-condensing polymer in gene delivery studies. Luciferase expression was significantly improved compared to the control $\mathrm{H}_{5} \mathrm{~K}_{10}$ non-amphiphilic peptide. Interestingly, TEM revealed that micelles of the two amphiphilic peptides studied had a cubic morphology, as did the complexes with DNA. ${ }^{105}$ Simultaneous delivery of a drug and gene was investigated using Ac- $(\mathrm{AF})_{6} \mathrm{H}_{5} \mathrm{~K}_{15}-\mathrm{NH}_{2} \cdot{ }^{106}$ The model drug employed was doxorubicin and the model genes were luciferase reporter gene or p53. The amphiphilic peptide was found to self-assemble into micelles, above a $\mathrm{cmc}$. These micelles were able to encapsulate doxorubicin and condense DNA. Co-delivery and in vitro expression were demonstrated using HepG2 cells. Amphiphilic peptides containing oligo-arginine repeats have also been shown to be efficient in gene delivery. ${ }^{107}$ Octa-arginine repeats were found to be optimal, and incorporation of histidine groups aids endosomal escape since the imidazole sidegroup is able to scavenge protons upon internalization in acid intra-cellular compartments.

The bioresponsive delivery of the anticancer agent cisplatin using a PA has been examined. ${ }^{108}$ The PA contained a cell-adhesive MMP-2 sensitive peptide domain and it was shown to self-assembled into fibrils. Hydrogelation was induced by complexation of the D residues or carboxyl termini in the peptide with cisplatin (Fig. 
12). Release of cisplatin by enzymatic degradation of the MMP-2 sensitive sequence was demonstrated.

Kros and coworkers have developed a simple PA-based model for membrane fusion, based on models for SNARE [soluble NSF attachment protein receptor, NSF = nethylmaleimide-sensitive factor] proteins. ${ }^{109}$ The PAs comprise DOPE lipid chains linked via PEG $_{12}$ spacers to coil peptides containing heptad repeats which contain complementary E and K residues (Table 1). By creating populations of liposomes with either of the two PAs incorporated in the lipid membrane, membrane fusion could be induced by mixing the liposomes which causes coiled coil formation due to salt bridging of the complementary residues.

\subsection{Antimicrobial Properties}

Lipidation of cationic peptides can improve their antimicrobial properties, as highlighted by Tirrell and coworkers. ${ }^{110}$ They showed enhanced antibacterial activity for two of the three PAs studied, but not the third which differed in sequence and had a lower increase in $\alpha$-helical content upon conjugation of the lipid chain than the other two. Changes in secondary structure in the presence of liposomes were probed by $\mathrm{CD}$. This led to the overall conclusion that increases in haemolytic activity and antimicrobial activity are correlated to changes in a-helical structure as the peptides interact with lipid membranes and that PAs can promote this, by enhancing the ability to form secondary structures. Shai and coworkers investigated the influence of PAs containing cationic K-based di- and tri-peptides on antimicrobial and antifungal activity using a range of Gram-negative and Gram-positive bacteria, and two fungal strains. ${ }^{111}$ The mode of action was identified as bacterial leakage caused by 
permeation and disruption of cell membranes, in common with many other antimicrobial peptides and polymers. Potent in vivo activity against C. albicans was shown, using a mouse model. PAs $\mathrm{C}_{16}-\mathrm{KKK}$ and $\mathrm{C}_{16}-\mathrm{KGK}$ were most active. The substitution of selected ${ }^{\mathrm{L}} \mathrm{K}$ residues with ${ }^{\mathrm{D}} \mathrm{K}$ was found not to affect the activity of the lipopeptides. These authors also mentioned that antimicrobial lipopeptides are produced nonribosomally in bacteria and fungi during cultivation. ${ }^{111}$

A cholesterol-based amphiphilic peptide containing a TAT sequence has been shown to be an effective antimicrobial agent. ${ }^{112}$ TAT peptides are widely used to transport peptides and proteins across cell membranes, ${ }^{113}$ and a short TAT domain was attached to a polyarginine sequence to further improve membrane translocation, and to confer antimicrobial properties. The amphiphilic peptides self-assemble into micelles and were shown to be effective against $S$. aureus infection in mice and rabbits. In the latter case, transport across the blood-brain barrier and reduction of bacterial growth in infected brains was demonstrated. ${ }^{112}$

PAs with potential application in the treatment of sepsis has been investigated. ${ }^{114}$ Sepsis is produced by bacterial endotoxins, lipopolysaccharides (LPS). These are a major component of the cell wall of Gram-negative bacteria. The immune system can recognise LPS and this was used as basis to design a PA based on an LPS binding cyclic 14-residue peptide (LALF). The LPS neutralizing activity was assayed and found to increase with alkyl chain length. Cytotoxicity was also examined. The PAs were found to self-assemble into micelles. Two other LPS-binding peptide sequences termed BPI and SAP were incorporated into $\mathrm{C}_{16} \mathrm{PAs}$ - these self-assembled into fibrils. ${ }^{114}$ 
As described above, the antimicrobial properties of $A_{3} K, A_{6} K$ and $A_{9} K$ have also been investigated. ${ }^{27}$

\subsection{Biomineralization}

The biomineralization of the artificial bone mineral hydroxyapatite can be templated using PAs. ${ }^{115,116}$ In the first demonstration of this concept, the design of the PA was carefully explained. The peptide comprises sequentially a $\mathrm{C}_{4}$ group which can be crosslinked to form disulfide links, a flexible $G_{3}$ spacer, a phosphorylated serine residue to interact with calcium ions and a terminal RGD cell adhesion motif (Table 1). Self-assembly into nanofibrils was reversible by variation of $\mathrm{pH}$ and the oxidative cross-linking via disulfide bond formation is also reversible upon addition of a reducing agent such as DTT. ${ }^{115}$ A nanofiber gel matrix can be used to template hydroxyapatite crystallization via the enzyme alkaline phosphatase in the presence of $\beta$-glycerolphosphate as a source of organic phosphate. Hydrogelation was induced by addition of calcium chloride which screens charge and enables ionic bridging to create a network structure in the self-supporting gel. Control experiments using collagen or alginate gels showed that mineralization did not occur using these systems as matrices. $^{116}$

A lipopeptide comprising a phospholipid (DOPE, dioleoyl phosphatidyl ethanolamine) conjugated to a (LG) $)_{4}$ octapeptide has been used to template the biomineralization of $\mathrm{Ca}^{2+}$, generating a distinct crystal habit of calcite. ${ }^{117}$ The peptide sequence is based on a design shown to form $\beta$-pleated sheet structures at the air/water interface. Attachment of the lipid chain enhanced amphiphilicity, and an 
ordered antiparallel $\beta$-sheet structure was formed that exposed an array of carboxylate groups to the aqueous phase, templating the formation of specific crystal orientations of $\mathrm{CaCO}_{3}$.

\subsection{Miscellaneous Applications}

Several SLPs were shown to be effective in enhancing the stability of membrane proteins in solution. ${ }^{118,119}$ Peptides $\mathrm{A}_{6} \mathrm{D}$ and $\mathrm{A}_{6} \mathrm{~K}$ were shown, via rhodopsin UV/vis adsorption kinetic measurements, to stabilize G-protein coupled receptor bovine rhodopsin against thermal denaturing with or without surfactants (lipids or other surfactants). ${ }^{118}$ Use of SLPs to improve the photochemical activity of the multidomain protein complex Photosystem-I (PS-I) was also demonstrated, as has the stabilization of PS-I in its functional form in aqueous solution, in terms of kinetic or thermal stability. ${ }^{119}$ The most active compounds were $\mathrm{Ac}-\mathrm{I}_{6} \mathrm{~K}_{2}-\mathrm{CONH} \mathrm{H}_{2}$ and Ac- $\mathrm{A}_{6} \mathrm{~K}-\mathrm{CONH} \mathrm{H}_{2}$ This type of SLP (specifically the latter compound) has also been used to stabilize PSI for use in solid-state electronic devices (photodetectors and photovoltaic devices), ${ }^{120}$ since it can stabilize the protein on a dry surface for an extended period. ${ }^{121}$

Synthetic virus-like particles based on PA micelles have been shown to stimulate antibody production based on model synthetic antigens. ${ }^{122}$ The antigens were presented on the surface of the self-assembled nanoparticles. The peptide component of the PA was a coiled-coil sequence derivd from the heptad repeat region 1 (HR1) from the $F_{1}$ glycoprotein of respiratory syncytial virus. The work has the potential to be extended to biologically relevant epitopes such as T-helper cell epitopes. 
Use of PAs as mild denaturing agents has been described. The lipopeptides form cylindrical micelles, presenting $\alpha$-helical peptide at the periphery. ${ }^{123}$ The dispersal of phospholipid membranes was ascribed to the ability of the alkyl chains in the PA to pack in a membrane-like manner.

PAs have been used to create bioactive micelles with applications as potential targetselective contrast agents for MRI. ${ }^{124}$ The PAs self-assembled into micelles presenting octreotide on the exterior, forming an antiparallel $\beta$-sheet structure. Octreotide is a cyclic eight residue somatostatin analogue, which could be capable of targeting receptors for human tumors.

The encapsulation of carbon nanotubes by PAs has been investigated. ${ }^{125}$ The branched PAs employed (anionic or cationic model systems) act as surfactants, with the additional advantage that biofunctionality (demonstrated using the RGD cell adhesion motif) can be introduced at the nanotube surface. The presentation of biotin on

RGDS-containing nanofibers formed by branched PAs has also been examined. ${ }^{126}$

\section{Conclusions}

Amphiphilic peptides are beginning to attract immense interest due to their outstanding potential in biomedical and bionanotechnological applications. Their selfassembly can be controlled in order to present bioactive peptides at the surface of fibrils, tubes, vesicles and other self-organized structures. Considering the potential of these materials compared to say, lipids or peptides as individual components, the literature to date is surprisingly quite limited. Although possibly not complete (we 
apologise to authors of work we have omitted), there appear to only be $\sim 100$-200 papers on this subject to date. We expect an explosion of further research in this area as new directions open up.

Undoubtedly, fibrils are the most commonly observed self-assembled structures for amphiphilic peptides. Vesicular and tape-like structures have also been observed. It would appear that the observation of these morphologies can be rationalised based on the geometrical surfactant packing parameter model. ${ }^{127}$ However, this has not yet been quantitatively investigated for amphiphilic peptides. It has been used as a general rule to understand the formation of vesicles, cylindrical and spherical micelles by amphiphilic block copolymers. ${ }^{128}$

In this review, details are provided on the self-assembly of amphiphilic peptides of which most work has been on model de novo designed surfactant-like peptides such as $A_{6} K$ and $A_{6} D$. Despite this work, basic questions such as the structure of the selfassembled structures have not until very recently been elucidated in detail and there are still outstanding important questions, such as what drives the formation of nanotubes and what sets the thickness of the nanotube wall, whether it is a single- or multi-wall nanotube. We have seen that these simple peptides may have important applications e.g. in antibacterial coatings due to the ability of short cationic sequences in amphiphilic peptides to disrupt cell membranes. It will be important to ensure in applications that this occurs selectively with bacterial membranes, and not the cell membranes of eukaryotes. 
The field of PAs has recently generated a set of very high profile breakthroughs concerning use of these materials in bioengineering, specifically in the development of biomaterials for cell growth and controlled differentiation, with applications in tissue scaffolding, bone development, collagen production, nerve regeneration etc. There are many other outstanding applications in regenerative medicine that rely on the ability of PAs to self-assemble into structures with a lipidic core, around which peptide epitopes are presented at high density. It is hoped that this review provides a snapshot of a very dynamic research environment in this field. 


\section{References}

F. Versluis, H. R. Marsden, and A. Kros, Chem. Soc. Rev., 2010, 39, 3434. X. B. Zhao, F. Pan, H. Xu, M. Yaseen, H. H. Shan, C. A. E. Hauser, S. G. Zhang, and J. R. Lu, Chem. Soc. Rev., 2010, 39, 3480.

D. W. P. M. Löwik and J. C. M. van Hest, Chem. Soc. Rev., 2004, 33, 234.

S. Cavalli and A. Kros, Adv. Mater., 2008, 20, 627.

H. G. Cui, M. J. Webber, and S. I. Stupp, PeptideScience, 2010, 94, 1.

S. S. Santoso, S. Vauthey, and S. Zhang, Curr. Opin. Colloid Interface Sci., 2002, 7, 262.

S. G. Zhang, Nature Biotechnology, 2003, 21, 1171.

X. Zhao and S. Zhang, Trends in Biotechnology, 2004, 22, 470.

D. W. P. M. Löwik, L. Ayres, J. M. Smeenk, and J. C. M. van Hest, Adv. Polym. Sci., 2006, 202, 19.

J. C. M. Van Hest, J. Macromol. Sci., Part C, Polym. Rev., 2007, 47, 63.

H. G. Börner and H. Schlaad, Soft Matter, 2007, 3, 394.

H. A. Klok, Macromolecules, 2009, 42, 7990.

L. A. Canalle, D. W. P. M. Löwik, and J. C. M. van Hest, Chem. Soc. Rev., 2010, 39, 329.

B. Le Droumaguet and J. Nicolas, Polymer Chemistry, 2010, 1, 563.

S. Vauthey, S. Santoso, H. Gong, N. Watson, and S. Zhang, Proc. Natl. Acad. Sci. U. S. A., 2002, 99, 5355.

S. Santoso, W. Hwang, H. Hartman, and S. Zhang, Nano Letters, 2002, 2, 687. F. Pan, X. B. Zhao, S. Perumal, T. A. Waigh, J. R. Lu, and J. R. P. Webster, Langmuir, 26, 5690.

G. von Maltzahn, S. Vauthey, S. Santoso, and S. Zhang, Langmuir, 2003, 19, 4332.

A. Nagai, Y. Nagai, H. J. Qu, and S. G. Zhang, J. Nanosci. Nanotechnol., 2007, 7, 2246.

U. Khoe, Y. L. Yang, and S. G. Zhang, Macromol. Biosci., 2008, 8, 1060.

R. G. Ellis-Behnke, Y. X. Liang, S. W. You, D. K. C. Tay, S. G. Zhang, K. F. So, and G. E. Schneider, Proc. Natl. Acad. Sci. U. S. A., 2006, 103, 5054.

C. A. E. Hauser and S. G. Zhang, Chem. Soc. Rev., 2010, 39, 2780.

U. Khoe, Y. Yang, and S. Zhang, Langmuir, 2009, 25, 4111.

M. K. Baumann, M. Textor, and E. Reimhult, Langmuir, 2008, 24, 7645.

D. J. Adams, K. Holtzmann, C. Schneider, and M. F. Butler, Langmuir, 2007, 23, 12729.

H. Xu, J. Wang, S. Y. Han, J. Q. Wang, D. Y. Yu, H. Y. Zhang, D. H. Xia, X.

B. Zhao, T. A. Waigh, and J. R. Lu, Langmuir, 2009, 25, 4115.

C. X. Chen, F. Pan, S. Z. Zhang, J. Hu, M. W. Cao, J. Wang, H. Xu, X. B.

Zhao, and J. R. Lu, Biomacromolecules, 2010, 11, 402.

S. Bucak, C. Cenker, I. Nasir, U. Olsson, and M. Zackrisson, Langmuir, 2009, 25, 4262.

V. Castelletto, D. R. Nutt, I. W. Hamley, S. Bucak, C. Cenker, and U. Olsson, Chem. Comm., 2010, 6270.

A. Yaghmur, P. Laggner, S. G. Zhang, and M. Rappolt, Plos One, 2007, 2.

T. J. Deming, Nature, 1997, 390, 386.

A. P. Nowak, V. Breedveld, L. Pakstis, B. Ozbas, D. J. Pine, D. Pochan, and T. J. Deming, Nature, 2002, 417, 424. 
D. J. Pochan, L. Pakstis, B. Ozbas, A. P. Nowak, and T. J. Deming, Macromolecules, 2002, 35, 5358.

E. G. Bellomo, M. D. Wyrsta, L. Pakstis, D. J. Pochan, and T. J. Deming, Nature Mater., 2004, 3, 244.

E. P. Holowka, D. J. Pochan, and T. J. Deming, J. Am. Chem. Soc., 2005, 127, 12423.

E. P. Holowka, V. Z. Sun, D. T. Kamei, and T. J. Deming, Nature Mater., 2007, 6, 52.

J. N. Cha, G. D. Stucky, D. E. Morse, and T. J. Deming, Nature, 2000, 403, 289.

M. S. Wong, J. N. Cha, K.-S. Choi, T. J. Deming, and G. D. Stucky, Nano Letters, 2002, 2, 583.

I. W. Hamley Soft Matter, 2005, 1, 36.

A. J. van Hell, C. I. C. A. Costa, F. M. Flesch, M. Sutter, W. Jiskoot, D. J. A.

Crommelin, W. E. Hennink, and E. Mastrobattista, Biomacromolecules, 2007, 8, 2753.

H. H. Shen, R. K. Thomas, C. Y. Chen, R. C. Darton, S. C. Baker, and J. Penfold, Langmuir, 2009, 25, 4211.

T. B. Schuster, D. de Bruyn Ouboter, E. Bordignon, G. Jeschke, and W. Meier, Soft Matter, 2010, 6, 5596.

J. D. Hartgerink, E. Beniash, and S. I. Stupp, Proc. Natl. Acad. Sci. U. S. A., 2002, 99, 5133.

M. A. Greenfield, J. R. Hoffman, M. O. de la Cruz, and S. I. Stupp, Langmuir, 2010, 26, 3641.

E. T. Pashuck, H. Cui, and S. I. Stupp, J. Am. Chem. Soc., 2010, 132, 6041.

J. D. Tovar, R. C. Claussen, and S. I. Stupp, J. Am. Chem. Soc., 2005, 127, 7337.

K. L. Niece, J. D. Hartgerink, J. J. J. M. Donners, and S. I. Stupp, J. Am. Chem. Soc., 2003, 125, 7146.

H. A. Behanna, J. Donners, A. C. Gordon, and S. I. Stupp, J. Am. Chem. Soc., 2005, 127, 1193.

R. C. Claussen, B. M. Rabatic, and S. I. Stupp, J. Am. Chem. Soc., 2003, 125, 12680.

R. M. Capito, H. S. Azvedo, Y. S. Velichko, A. Mata, and S. I. Stupp, Science, 2008, 319, 1812.

Y. S. Velichko, S. I. Stupp, and M. Olvera de la Cruz, J. Phys. Chem. B, 2008, 112, 2326.

H. Cui, T. Muraoka, A. G. Cheetham, and S. I. Stupp, Nano Letters, 2009, 9, 945.

E. T. Pashuck and S. I. Stupp, J. Am. Chem. Soc., 2010, 132, 8819.

M. O. Guler, L. Hsu, S. Soukasene, D. A. Harrington, J. F. Hulvat, and S. I. Stupp, Biomacromolecules, 2006, 7, 1855.

L.-S. Li and S. I. Stupp, Angew. Chem., Int. Ed. Engl., 2005, 44, 1833.

H. G. Cui, E. T. Pashuck, Y. S. Velichko, S. J. Weigand, A. G. Cheetham, C. J. Newcomb, and S. I. Stupp, Science, 2010, 327, 555.

S. M. Zhang, M. A. Greenfield, A. Mata, L. C. Palmer, R. Bitton, J. R. Mantei, C. Aparicio, M. O. de la Cruz, and S. I. Stupp, Nature Mater., 2010, 9, 594. M. L. de la Paz, K. Goldie, J. Zurdo, E. Lacroix, C. M. Dobson, A. Hoenger, and L. Serrano, Proc. Natl. Acad. Sci. U. S. A., 2002, 99, 16052. 
J. T. Meijer, M. Roeters, V. Viola, D. W. P. M. Löwik, G. Vriend, and J. C. M. van Hest, Langmuir, 2007, 23, 2058.

J. T. Meijer, M. Henckens, I. J. Minten, D. Lowik, and J. C. M. van Hest, Soft Matter, 2007, 3, 1135.

D. W. P. M. Löwik, J. Garcia-Hartjes, J. T. Meijer, and J. C. M. van Hest, Langmuir, 2005, 21, 524.

M. van den Heuvel, D. W. P. M. Löwik, and J. C. M. van Hest, Biomacromolecules, 2010, 11, 1676.

M. van den Heuvel, A. M. Prenen, J. C. Gielen, P. C. M. Christianen, D. J. Broer, D. Lowik, and J. C. M. van Hest, J. Am. Chem. Soc., 2009, 131, 15014. D. W. P. M. Löwik, I. O. Shklyarevskiy, L. Ruizendaal, P. C. M. Christianen, J. C. Maan, and J. C. M. van Hest, Adv. Mater., 2007, 19, 1191.

S. E. Paramonov, H.-W. Jun, and J. D. Hartgerink, J. Am. Chem. Soc., 2006, 128, 7291.

V. M. Yuwono and J. D. Hartgerink, Langmuir, 2007, 23, 5033.

D. J. Gordon, J. J. Balbach, R. Tycko, and S. C. Meredith, Biophys. J., 2004, 86, 428.

P. Berndt, G. B. Fields, and M. Tirrell, J. Am. Chem. Soc., 1995, 117, 9515.

S. Cavalli, J. W. Handgraaf, E. E. Tellers, D. C. Popescu, M. Overhand, K.

Kjaer, V. Vaiser, N. Sommerdijk, H. Rapaport, and A. Kros, J. Am. Chem. Soc., 2006, 128, 13959.

M. Deng, D. Yu, Y. Hou, and Y. Wang, J. Phys. Chem. B, 2009, 113, 8539.

R. C. Elgersma, T. Meijneke, R. de Jong, A. J. Brouwer, G. Posthuma, D. T. S. Rijkers, and R. M. J. Liskamp, Organic \& Biomolecular Chemistry, 2006, 4, 3587.

Y. C. Yu, P. Berndt, M. Tirrell, and G. B. Fields, J. Am. Chem. Soc., 1996, 118, 12515.

Y. C. Yu, M. Tirrell, and G. B. Fields, J. Am. Chem. Soc., 1998, 120, 9979.

P. Forns, J. L. Lauer-Fields, S. Gao, and G. B. Fields, Biopolymers, 2000, 54, 531.

T. Shimada, S. Lee, F. S. Bates, A. Hotta, and M. Tirrell, J. Phys. Chem. B, 2009, 113, 13711.

Y. Jin, X.-D. Xu, C.-S. Chen, S.-X. Cheng, X.-Z. Zhang, and R.-X. Zhuo, Macromol.Rapid Comm., 2009, 29, 1726.

R. Bitton, J. Schmidt, M. Biesalski, R. Tu, M. Tirrell, and H. Bianco-Peled, Langmuir, 2005, 21, 11888.

T. Pakalns, K. L. Haverstick, G. B. Fields, J. B. McCarthy, D. L. Mooradian, and M. Tirrell, Biomaterials, 1999, 20, 2265.

N. Oku, C. Koike, Y. Tokudome, S. Okada, N. Nishikawa, H. Tsukada, M. Kiso, A. Hasegawa, H. Fujii, J. Murata, and I. Saiki, Adv Drug Deliv Rev, 1997, 24, 215.

V. Marchi-Artzner, B. Lorz, C. Gosse, L. Jullien, R. Merkel, H. Kessler, and E. Sackmann, Langmuir, 2003, 19, 835.

V. Marchi-Artzner, B. Lorz, U. Hellerer, M. Kantlehner, H. Kessler, and E. Sackmann, Chem. Eur. J., 2001, 7, 1095.

N. B. Malkar, J. L. Lauer-Fields, D. Juska, and G. B. Fields, Biomacromolecules, 2003, 4, 518.

H. W. Jun, S. E. Paramonov, H. Dong, N. Forraz, C. McGuckin, and J. D. Hartgerink, J. Biomater. Sci.-Polym. Ed., 2008, 19, 665. 
G. A. Silva, C. Czeisler, K. L. Niece, E. Beniash, D. A. Harrington, J. A. Kessler, and S. I. Stupp, Science, 2004, 303, 1352.

V. M. Tysseling-Mattiace, V. Sahni, K. L. Niece, D. Birch, C. Czeisler, M. G. Fehlings, S. I. Stupp, and J. A. Kessler, J. Neurosci., 2008, 28, 3814.

M. J. Webber, J. Tongers, M.-A. Renault, J. G. Roncalli, D. W. Losordo, and S. I. Stupp, Acta Biomater., 2010, 6, 3.

R. N. Shah, N. A. Shah, M. M. D. Lim, C. Hsieh, G. Nuber, and S. I. Stupp, Proc. Natl. Acad. Sci. U. S. A., 2009, 107, 3293.

K. Rajangam, H. A. Behanna, M. J. Hui, X. Q. Han, J. F. Hulvat, J. W. Lomasney, and S. I. Stupp, Nano Letters, 2006, 6, 2086.

A. Mata, L. Hsu, R. Capito, C. Aparicio, K. Henrikson, and S. I. Stupp, Soft Matter, 2009, 5, 1228.

A. M. Hung and S. I. Stupp, Nano Letters, 2007, 7, 1165.

K. Lintner, in 'Compositions containing mixtures of tetrapeptides and tripeptides', ed. U. S. P. Organization, USA, 2004.

L. R. Robinson, N. C. Fitzgerald, D. G. Doughty, N. C. Dawes, C. A. Berge, and D. L. Bissett, International Journal of Cosmetic Science, 2005, 27, 155.

R. I. Chirita, P. Chaimbault, J. C. Archambault, I. Robert, and C. Elfakir, Anal. Chim. Acta, 2009, 641, 95.

R. Osborne, L. A. Mullins, and B. B. Jarrold, Journal of Drugs in

Dermatology, 2009, 8, s4.

S. H. Weinkle and H. L. Hall, in 'Cosmeceutical Peptides', ed. N. S. Sadick, M.

P. Lupo, D. S. Berson, and Z. D. Draelos, London, 2010.

V. Castelletto, I. W. Hamley, J. Perez, L. Abezgauz, and D. Danino, Chem.

Comm., 2010, 46.

E. Kokkoli, S. E. Ochsenhirt, and M. Tirrell, Langmuir, 2004, 20, 2397.

A. Mardilovich and E. Kokkoli, Biomacromolecules, 2004, 5, 950.

A. Mardilovich, J. A. Craig, M. Q. McCammon, A. Garg, and E. Kokkoli, Langmuir, 2006, 22, 3259.

J. A. Craig, E. L. Rexeisen, A. Mardilovich, K. Shroff, and E. Kokkoli, Langmuir, 2008, 24, 10282.

K. Shroff, E. L. Rexeisen, M. A. Arunagirinatham, and E. Kokkoli, Soft Matter, 2010, 6, 5064.

S. Keller, I. Sauer, H. Strauss, K. Gast, M. Dathe, and M. Bienert, Angew.

Chem. Int. Ed. Engl., 2005, 44, 5252.

D. Missirlis, H. Khant, and M. Tirrell, Biochemistry, 2009, 48, 3304.

X. D. Guo, F. Tandiono, N. Wiradharma, D. Khor, C. G. Tan, M. Khan, Y. Qian, and Y. Y. Yang, Biomaterials, 2008, 29, 4838.

N. Wiradharma, M. Khan, Y. W. Tong, S. Wang, and Y. Y. Yang, Advanced Functional Materials, 2008, 18, 943.

N. Wiradharma, Y. W. Tong, and Y. Y. Yang, Biomaterials, 2009, 30, 3100.

W. Y. Seow and Y. Y. Yang, Adv. Mater., 2009, 21, 86.

J. K. Kim, J. Anderson, H. W. Jun, M. A. Repka, and S. Jo, Mol. Pharm., 2009, 6, 978.

H. R. Marsden, N. A. Elbers, P. H. H. Bomans, N. A. J. M. Sommerdijk, and

A. Kros, Angew. Chem., Int. Ed. Engl., 2009, 48, 2330.

A. F. Chu-Kung, K. N. Bozzelli, N. A. Lockwood, J. R. Haseman, K. H. Mayo, and M. V. Tirrell, Bioconjugate Chemistry, 2004, 15, 530.

A. Makovitzki, J. Baram, and Y. Shai, Biochemistry, 2008, 47, 10630. 
L. H. Liu, K. J. Xu, H. Y. Wang, P. K. J. Tan, W. M. Fan, S. S. Venkatraman, L. J. Li, and Y. Y. Yang, Nature Nanotech, 2009, 4, 457.

J. S. Wadia, R. V. Stan, and S. F. Dowdy, Nature Medicine, 2004, 10, 310.

Albericio, ChemMedChem, 2008, 3, 1748.

J. D. Hartgerink, E. Beniash, and S. I. Stupp, Science, 2001, 294, 1684.

E. D. Spoerke, S. G. Anthony, and S. I. Stupp, Adv. Mater., 2009, 21, 425.

S. Cavalli, D. C. Popescu, E. E. Tellers, M. R. J. Vos, B. P. Pichon, M.

Overhand, H. Rapaport, N. Sommerdijk, and A. Kros, Angew. Chem. Int. Ed. Engl., 2006, 45, 739.

X. J. Zhao, Y. Nagai, P. J. Reeves, P. Kiley, H. G. Khorana, and S. G. Zhang, Proc. Natl. Acad. Sci. U. S. A., 2006, 103, 17707.

K. Matsumoto, M. Vaughn, B. D. Bruce, S. Koutsopoulos, and S. G. Zhang, J. Phys. Chem. B, 2009, 113, 75.

R. Das, P. J. Kiley, M. Segal, J. Norville, A. A. Yu, L. Y. Wang, S. A.

Trammell, L. E. Reddick, R. Kumar, F. Stellacci, N. Lebedev, J. Schnur, B. D. Bruce, S. G. Zhang, and M. Baldo, Nano Letters, 2004, 4, 1079.

P. Kiley, X. J. Zhao, M. Vaughn, M. A. Baldo, B. D. Bruce, and S. G. Zhang, Plos Biology, 2005, 3, 1180.

F. Boato, R. M. Thomas, A. Ghasparian, A. Freund-Renard, K. Moehle, and J.

A. Robinson, Angew. Chem. Int. Ed. Engl., 2007, 46, 9015.

C. L. McGregor, L. Chen, N. C. Pomroy, P. Hwang, S. Go, A. Chakrabartty, and G. G. Prive, Nature Biotechnology, 2003, 21, 171.

A. Morisco, A. Accardo, E. Gianolio, D. Tesauro, E. Benedetti, and G. Morelli, J. Pept. Sci., 2009, 15, 242.

M. S. Arnold, M. O. Guler, M. C. Hersam, and S. I. Stupp, Langmuir, 2005, 21, 4705.

M. O. Guler, S. Sousakene, J. F. Hulvat, and S. I. Stupp, Nano Letters, 2005, 5, 249.

J. N. Israelachvili, 'Intermolecular and Surface Forces', Academic Press, 1991. A. Blanazs, S. P. Armes, and A. J. Ryan, Macromol.Rapid Comm., 2009, 30, 267.

J. T. Meijer, M. Roeters, V. Viola, D. Lowik, G. Vriend, and J. C. M. van Hest, Langmuir, 2007, 23, 2058.

V. Castelletto, I. W. Hamley, J. Perez, L. Abezgauz, and D. Danino, Chem.

Comm., 2010, 46, 9185. 
Table 1. Amphiphilic peptide systems*

\begin{tabular}{|c|c|c|c|}
\hline Amphiphilic Peptide & $\begin{array}{l}\text { Peptide } \\
\text { Design }\end{array}$ & Nature of Study & Ref. \\
\hline \multicolumn{4}{|l|}{ Surfactant-Like Peptides } \\
\hline $\mathrm{A}_{6} \mathrm{D}, \mathrm{V}_{6} \mathrm{D}, \mathrm{V}_{6} \mathrm{D}_{2}, \mathrm{~L}_{6} \mathrm{D}_{2}$ & $\begin{array}{l}\text { de novo } \\
\text { design }\end{array}$ & Nanotube formation & 15 \\
\hline $\mathrm{G}_{4} \mathrm{D}_{2}, \mathrm{G}_{6} \mathrm{D}_{2}, \mathrm{G}_{8} \mathrm{D}_{2}, \mathrm{G}_{10} \mathrm{D}_{2}$ & $\begin{array}{l}\text { de novo } \\
\text { design }\end{array}$ & $\begin{array}{l}\text { Nanotube and vesicle } \\
\text { formation }\end{array}$ & 16 \\
\hline $\mathrm{V}_{6} \mathrm{~K}, \mathrm{~V}_{6} \mathrm{~K}_{2}, \mathrm{~V}_{3} \mathrm{~K}$ & $\begin{array}{l}\text { de novo } \\
\text { design }\end{array}$ & $\begin{array}{l}\text { Adsorption at the } \\
\text { air/solid interface, } \\
\text { DNA immobilization }\end{array}$ & 17 \\
\hline $\mathrm{V}_{6} \mathrm{~K}_{2}, \mathrm{~L}_{6} \mathrm{~K}_{2}, \mathrm{~A}_{6} \mathrm{~K}, \mathrm{~V}_{6} \mathrm{H}, \mathrm{V}_{6} \mathrm{~K}, \mathrm{H}_{2} \mathrm{~V}_{6}, \mathrm{KV}_{6}$ & $\begin{array}{l}\text { de novo } \\
\text { design }\end{array}$ & $\begin{array}{l}\text { Nanotube and vesicle } \\
\text { formation }\end{array}$ & 18 \\
\hline Ac- $\mathrm{A}_{6} \mathrm{D}-\mathrm{COOH}$ and $\mathrm{Ac}-\mathrm{A}_{6} \mathrm{~K}-\mathrm{COOH}$ & $\begin{array}{l}\text { de novo } \\
\text { design }\end{array}$ & $\begin{array}{l}\text { Self-assembly and cac } \\
\text { determination }\end{array}$ & 19 \\
\hline Mixtures of Ac- $\mathrm{A}_{6} \mathrm{D}-\mathrm{OH}$ and $\mathrm{Ac}-\mathrm{A}_{6} \mathrm{~K}-\mathrm{NH}_{2}$ & $\begin{array}{l}\text { de novo } \\
\text { design }\end{array}$ & $\begin{array}{l}\text { Synergistic effects on } \\
\text { cac, and observation of } \\
\text { twisted fibrils }\end{array}$ & 20 \\
\hline Ac-GAVILRR-NH ${ }_{2}$ & $\begin{array}{l}\text { de novo } \\
\text { design }\end{array}$ & $\begin{array}{l}\text { Formation of } \\
\text { "nanodonut" structures }\end{array}$ & 23 \\
\hline $\mathrm{I}_{6} \mathrm{~K}_{2}, \mathrm{~L}_{6} \mathrm{~K}_{2}, \mathrm{~V}_{6} \mathrm{~K}_{2}$ & $\begin{array}{l}\text { de novo } \\
\text { design }\end{array}$ & $\begin{array}{l}\text { Self-assembled } \\
\text { morphology correlated } \\
\text { to secondary structure }\end{array}$ & 24 \\
\hline $\mathrm{V}_{6} \mathrm{D}_{2}, \mathrm{~V}_{5} \mathrm{DVD}, \mathrm{V}_{4} \mathrm{D}_{2} \mathrm{~V}_{2}$ & $\begin{array}{l}\text { de novo } \\
\text { design }\end{array}$ & $\begin{array}{l}\text { Influence of sequence } \\
\text { and purity on self- } \\
\text { assembly }\end{array}$ & 25 \\
\hline \multirow[t]{2}{*}{$\mathrm{A}_{3} \mathrm{~K}, \mathrm{~A}_{6} \mathrm{~K}, \mathrm{~A}_{9} \mathrm{~K}$} & \multirow[t]{2}{*}{$\begin{array}{l}\text { de novo } \\
\text { design }\end{array}$} & $\begin{array}{l}\text { Determination of cmc, } \\
\text { self-assembled } \\
\text { structures }\end{array}$ & 26 \\
\hline & & Antibacterial properties & 27 \\
\hline \multirow[t]{2}{*}{$\mathrm{A}_{6} \mathrm{~K}$} & \multirow{2}{*}{$\begin{array}{l}\text { de novo } \\
\text { design }\end{array}$} & Nanotube formation & 28 \\
\hline & & Nanotube structure & 29 \\
\hline $\begin{array}{l}\mathrm{Ac}_{-} \mathrm{A}_{2} \mathrm{~V}_{2} \mathrm{~L}_{3} \mathrm{WG}_{2}-\mathrm{COOH} \text { and } \mathrm{Ac}-\mathrm{A}_{2} \mathrm{~V}_{2} \mathrm{~L}_{3} \mathrm{WG}_{7^{-}} \\
\mathrm{COOH}\end{array}$ & $\begin{array}{l}\text { de novo } \\
\text { design }\end{array}$ & Formation of vesicles & 40 \\
\hline $\begin{array}{l}\text { chol- } \mathrm{H}_{5} \mathrm{R}_{10} \text {, chol- } \mathrm{H}_{10} \mathrm{R}_{10} \\
\text { chol denotes cholesterol }\end{array}$ & $\begin{array}{l}\text { de novo } \\
\text { design }\end{array}$ & Gene delivery & 104 \\
\hline $\begin{array}{l}\mathrm{A}_{12} \mathrm{H}_{5} \mathrm{~K}_{10}, \mathrm{~A}_{12} \mathrm{H}_{5} \mathrm{~K}_{15} \text { and } \mathrm{H}_{5} \mathrm{~K}_{10} \text { (non-amphiphilic } \\
\text { control) }\end{array}$ & $\begin{array}{l}\text { de novo } \\
\text { design }\end{array}$ & Gene delivery & 105 \\
\hline Ac- $(\mathrm{AF})_{6} \mathrm{H}_{5} \mathrm{~K}_{15}-\mathrm{NH}_{2}$ & $\begin{array}{l}\text { de novo } \\
\text { design }\end{array}$ & $\begin{array}{l}\text { Co-delivery of drug and } \\
\text { DNA (gene delivery) }\end{array}$ & 106 \\
\hline $\begin{array}{l}\mathrm{NH}_{2}-\mathrm{I}_{5} \mathrm{H}_{4} \mathrm{R}_{8}-\mathrm{CONH}_{2}, \mathrm{NH}_{2}-\mathrm{F}_{5} \mathrm{H}_{4} \mathrm{R}_{8}-\mathrm{CONH}_{2}, \\
\mathrm{NH}_{2}-\mathrm{W}_{5} \mathrm{H}_{4} \mathrm{R}_{8}-\mathrm{CONH}_{2}, \mathrm{NH}_{2}-\mathrm{H}_{4} \mathrm{R}_{8}-\mathrm{CONH}_{2},\end{array}$ & $\begin{array}{l}\text { de novo } \\
\text { design }\end{array}$ & Gene delivery & 107 \\
\hline $\begin{array}{l}\text { chol-G }{ }_{3} R_{6} \text { TAT } \\
\text { TAT }=\text { YGRKKRRQRRR }\end{array}$ & $\begin{array}{l}\text { Contains } \\
\text { TAT } \\
\text { sequence }\end{array}$ & Antimicrobial properties & 112 \\
\hline $\mathrm{A}_{6} \mathrm{D}$ and $\mathrm{A}_{6} \mathrm{~K}$ & $\begin{array}{l}\text { de novo } \\
\text { design }\end{array}$ & $\begin{array}{l}\text { Stabilization of } \\
\text { G-protein coupled } \\
\text { receptor bovine }\end{array}$ & 118 \\
\hline
\end{tabular}




\begin{tabular}{|c|c|c|c|}
\hline & & $\begin{array}{l}\text { rhodopsin against } \\
\text { denaturing }\end{array}$ & \\
\hline $\begin{array}{l}\text { Ac- } \mathrm{V}_{6} \mathrm{R}_{2}-\mathrm{NH}_{2}, \mathrm{Ac}_{\mathrm{C}} \mathrm{V}_{6} \mathrm{~K}_{2}-\mathrm{NH}_{2}, \mathrm{Ac}-\mathrm{A}_{6} \mathrm{~K}-\mathrm{NH}_{2}, \mathrm{Ac}- \\
\mathrm{I}_{6} \mathrm{~K}_{2}-\mathrm{NH}_{2}, \mathrm{Ac}-\mathrm{A}_{6} \mathrm{~K}-\mathrm{OH}, \mathrm{DA}_{6}-\mathrm{NH}_{2}, \mathrm{Ac}_{-} \mathrm{V}_{6} \mathrm{D}_{2}-\mathrm{NH}_{2}, \\
\text { Ac- } \mathrm{A}_{6} \mathrm{D}-\mathrm{OH}, \mathrm{KA}_{6}-\mathrm{NH}_{2}\end{array}$ & $\begin{array}{l}\text { de novo } \\
\text { design }\end{array}$ & $\begin{array}{l}\text { Stabilization of } \\
\text { Protein complex } \\
\text { Photosystem-I and } \\
\text { enhancement of activity }\end{array}$ & $119-121$ \\
\hline $\begin{array}{l}\mathrm{H}-\mathrm{K}_{3}-\left[\mathrm{W}^{\mathrm{D}} \mathrm{L}\right]_{3}-\mathrm{W}-\mathrm{NH}_{2}, \mathrm{H}-\mathrm{CK}_{3}-\left[\mathrm{W}^{\mathrm{D}} \mathrm{L}\right]_{3}-\mathrm{W}-\mathrm{NH}_{2}, \\
\mathrm{Ac}-[\mathrm{K}(\mathrm{Ac})]_{3}-\mathrm{W}-\left[\mathrm{W}^{\mathrm{D}} \mathrm{L}\right]_{3}-\mathrm{W}-\mathrm{NH}_{2}, \mathrm{Ac}-\mathrm{C}[\mathrm{K}(\mathrm{Ac})]_{3}- \\
\mathrm{W}-\left[\mathrm{W}^{\mathrm{D}} \mathrm{L}\right]_{3}-\mathrm{W}-\mathrm{NH} \mathrm{H}_{2}, \mathrm{Ac}-\mathrm{C}(\mathrm{sl})[\mathrm{K}(\mathrm{Ac})]_{3}-\mathrm{W}-\left[\mathrm{W}^{\mathrm{D}} \mathrm{L}\right]_{3^{-}} \\
\mathrm{W}-\mathrm{NH}_{2} \\
\text { sl denotes the spin label acetamidoproxyl }\end{array}$ & $\begin{array}{l}\text { de novo } \\
\text { design }\end{array}$ & $\begin{array}{l}\text { Micelle aggregation and } \\
\text { formation of particles } \\
\text { and beads }\end{array}$ & 42 \\
\hline \multicolumn{4}{|l|}{ Lipidated Peptides } \\
\hline $\begin{array}{l}\mathrm{C}_{\mathrm{n}}-\mathrm{C}_{4} \mathrm{G}_{3} \mathrm{~S} \text { (Phos)RGD } \mathrm{n}=6,10,16,22 \\
\mathrm{C}_{\mathrm{n}}-\mathrm{A}_{4} \mathrm{G}_{3} \mathrm{~S} \text { (Phos)RGD } \mathrm{n}=10,16 \\
\mathrm{C}_{16}-\mathrm{C}_{4} \mathrm{G}_{3} \mathrm{~S} \text { (Phos), } \mathrm{C}_{16}-\mathrm{C}_{4} \mathrm{G}_{3} \mathrm{~S}(\mathrm{Phos}) \mathrm{KGE} \\
\mathrm{C}_{16}-\mathrm{C}_{4} \mathrm{G}_{3} \mathrm{~S} \text { (Phos)RGDS, } \mathrm{C}_{16}-\mathrm{C}_{4} \mathrm{G}_{3} \mathrm{SRGD}, \mathrm{C}_{16^{-}} \\
\mathrm{C}_{4} \mathrm{G}_{3} \text { EIKVAV } \\
\text { S(Phos) denotes phosphorylated serine }\end{array}$ & $\begin{array}{l}\text { de novo } \\
\text { design }\end{array}$ & $\begin{array}{l}\text { Influence of PA } \\
\text { structure on self- } \\
\text { assembly, and covalent } \\
\text { capture by disulfide } \\
\text { cross-linking }\end{array}$ & 43 \\
\hline $\mathrm{C}_{16} \mathrm{O}-\mathrm{V}_{3} \mathrm{~A}_{3} \mathrm{E}_{3}$ & $\begin{array}{l}\text { de novo } \\
\text { design }\end{array}$ & $\begin{array}{l}\text { Mechanical properties } \\
\text { of hydrogels }\end{array}$ & 44 \\
\hline $\begin{array}{l}\mathrm{C}_{16} \mathrm{O}-\mathrm{V}_{3} \mathrm{~A}_{3} \mathrm{E}_{3}, \mathrm{C}_{16} \mathrm{O}-\mathrm{V}_{2} \mathrm{~A}_{2} \mathrm{E}_{3}, \mathrm{C}_{16} \mathrm{O}-\mathrm{V}_{4} \mathrm{~A}_{4} \mathrm{E}_{3}, \mathrm{C}_{16} \mathrm{O}- \\
\mathrm{V}_{2} \mathrm{~A}_{4} \mathrm{E}_{3}, \mathrm{C}_{16} \mathrm{O}-\mathrm{V}_{4} \mathrm{~A}_{2} \mathrm{E}_{3}, \mathrm{C}_{16} \mathrm{O}-\mathrm{A}_{3} \mathrm{~V}_{3} \mathrm{E}_{3}\end{array}$ & $\begin{array}{l}\text { de novo } \\
\text { design }\end{array}$ & $\begin{array}{l}\text { Influence of sequence } \\
\text { on hydrogen bond } \\
\text { alignment, fibril } \\
\text { twisting and gel } \\
\text { stiffness }\end{array}$ & 45 \\
\hline $\begin{array}{l}\text { GWVAVKIEG }_{3} \mathrm{~A}_{4}-\mathrm{OC}_{16} \\
\text { VAVKIEG }_{3} \mathrm{~A}_{4} \mathrm{~W}-\mathrm{OC}_{16} \\
\text { VAVKIEG }_{3} \mathrm{~A}_{4}-\mathrm{COC}_{3} \mathrm{H}_{6} \text {-Pyrene } \\
\mathrm{G}\left(\mathrm{K}-\mathrm{COCH}_{2} \mathrm{Pyrene}_{\mathrm{E}} \mathrm{EVAVKIEG}_{3} \mathrm{~A}_{4}-\mathrm{OC}_{16}\right. \\
\text { VAVKIEG }_{3} \mathrm{~A}_{4}\left(\mathrm{~K}-\mathrm{COCH}_{2} \text { Pyrene }_{-}-\mathrm{OC}_{16}\right. \\
\text { VAVKIEG }_{3} \mathrm{~A}_{4}-\mathrm{OC}_{16}\end{array}$ & $\begin{array}{l}\text { de novo } \\
\text { design }\end{array}$ & $\begin{array}{l}\text { Tryptophan and pyrene } \\
\text { fluorescence of } \\
\text { solvation of PA fibrils }\end{array}$ & 46 \\
\hline $\begin{array}{l}\mathrm{C}_{16} \mathrm{ONH}-\mathrm{A}_{4} \mathrm{G}_{3} \text { EIKVAV-COOH } \\
\mathrm{C}_{16} \mathrm{ONH}-\mathrm{A}_{4} \mathrm{G}_{3} \mathrm{KYIGSR}-\mathrm{CONH}{ }_{2} \\
\mathrm{C}_{16} \mathrm{ONH}-\mathrm{C}_{4} \mathrm{G}_{3} \mathrm{~S} \text { (Phos)RGDS-COOH } \\
\mathrm{C}_{16} \mathrm{ONH}-\mathrm{C}_{4} \mathrm{G}_{3} \mathrm{KIKVAV-CONH} \mathrm{H}_{2}\end{array}$ & $\begin{array}{l}\text { de novo } \\
\text { design }\end{array}$ & $\begin{array}{l}\text { Coassembly of PAs with } \\
\text { oppositely charged } \\
\text { peptide sequences }\end{array}$ & 47 \\
\hline $\begin{array}{l}\mathrm{C}_{16} \mathrm{ONH}-\mathrm{V}_{3} \mathrm{~A}_{3} \mathrm{~K}_{3}-\mathrm{COOH}, \mathrm{C}_{16} \mathrm{ONH}-\mathrm{V}_{3} \mathrm{~A}_{3} \mathrm{E}_{3^{-}} \\
\mathrm{COOH}, \\
\left.\mathrm{C}_{12} \mathrm{ONHCO}-\mathrm{CH}_{2} \mathrm{CH}(\mathrm{CCONH})_{2}\right) \mathrm{V}_{6} \mathrm{~K}_{3}-\mathrm{NH}_{2}, \\
\left.\mathrm{C}_{12} \mathrm{ONHCO}-\mathrm{CH}_{2} \mathrm{CH}(\mathrm{CCONH})_{2}\right) \mathrm{V}_{3} \mathrm{~A}_{3} \mathrm{E}_{3}-\mathrm{NH}_{2} \text {, }\end{array}$ & $\begin{array}{l}\text { de novo } \\
\text { design }\end{array}$ & $\begin{array}{l}\text { Mixing of PAs with free } \\
\text { C- and N- termini }\end{array}$ & 48 \\
\hline $\begin{array}{l}\text { COOH-GE } \mathrm{L}_{3} \mathrm{~L}_{3}-\mathrm{COC}_{5} \mathrm{H}_{10} \text {-(urea oligomer) } \\
\mathrm{COOH}-\mathrm{GE}_{3} \mathrm{~L}_{3}-\mathrm{COC}_{5} \mathrm{H}_{10} \text {-(urea oligomer) } \\
\mathrm{COOH}-\mathrm{E}_{3} \mathrm{~L}_{3}-\mathrm{COC}_{5} \mathrm{H}_{10} \text {-(urea oligomer) }\end{array}$ & $\begin{array}{l}\text { de novo } \\
\text { design }\end{array}$ & $\begin{array}{l}\text { Nanofibril formation by } \\
\text { asymmetric peptide } \\
\text { bolaamphiphiles }\end{array}$ & 49 \\
\hline $\mathrm{C}_{16}-\mathrm{V}_{3} \mathrm{~A}_{3} \mathrm{~K}_{3}$ & $\begin{array}{l}\text { de novo } \\
\text { design }\end{array}$ & $\begin{array}{l}\text { Formation of } \\
\text { macroscopic gels and } \\
\text { membranes at the } \\
\text { interface of PA and } \\
\text { hyaluronic acid } \\
\text { solutions }\end{array}$ & 50 \\
\hline
\end{tabular}




\begin{tabular}{|c|c|c|c|}
\hline $\mathrm{C}_{16} \mathrm{O}-\mathrm{VEVE}$ and $\mathrm{C}_{16} \mathrm{O}-\mathrm{VEVEGRGD}$ & $\begin{array}{l}\text { de novo } \\
\text { design }\end{array}$ & Nanobelt formation & 52 \\
\hline $\mathrm{C}_{16}-\mathrm{F}_{3} \mathrm{E}_{3}, \mathrm{C}_{16}-\mathrm{A}_{3} \mathrm{E}_{3}$ & $\begin{array}{l}\text { de novo } \\
\text { design }\end{array}$ & $\begin{array}{l}\text { Twisted ribbon to } \\
\text { helical ribbon transition }\end{array}$ & 53 \\
\hline $\begin{array}{l}\text { WRGDSG }_{3} \mathrm{~A}_{3}(\mathrm{~K})-\mathrm{C}_{16} \mathrm{O} \\
\mathrm{K}(\mathrm{WRGDS}-\mathrm{K}) \mathrm{KX}_{3} \mathrm{~A}_{3}(\mathrm{~K})-\mathrm{C}_{16} \mathrm{O} ; \mathrm{X}=\mathrm{G} \text { or } \mathrm{VCH}_{3} \\
\mathrm{~K}(\mathrm{RGDSW}-\mathrm{K}) \mathrm{KX}_{3} \mathrm{~A}_{3}(\mathrm{~K})-\mathrm{C}_{16} \mathrm{O} ; \mathrm{X}=\mathrm{G} \text { or } \mathrm{VCH}_{3} \\
\text { RGDSG }_{3} \mathrm{~A}_{3}(\mathrm{~K})-\mathrm{C}_{16} \mathrm{O} \\
\mathrm{K}(\mathrm{RGDS}-\mathrm{K}) \mathrm{KL}_{3} \mathrm{~A}_{3}(\mathrm{~K})-\mathrm{C}_{16} \mathrm{O} \\
(\mathrm{RGDS}-\mathrm{K}) \mathrm{K}(\mathrm{K}-\mathrm{RGDS}) \mathrm{L}_{3} \mathrm{~A}_{3}(\mathrm{~K})-\mathrm{C}_{16} \mathrm{O} \\
{ }^{\mathrm{D}} \mathrm{D}(\mathrm{RGDS}-\mathrm{D}) \mathrm{KL}_{3} \mathrm{~A}_{3}(\mathrm{~K})-\mathrm{C}_{16} \mathrm{O} \\
\text { K(GRSDSD-K)KL } \mathrm{KL}_{3} \mathrm{~A}_{3}(\mathrm{~K})-\mathrm{C}_{16} \mathrm{O} \underline{\text { RGDSD }} \text { denotes } \\
\text { cyclic peptide }\end{array}$ & $\begin{array}{l}\text { de novo } \\
\text { designs } \\
\text { incorporating } \\
\text { RGDS cell } \\
\text { adhesion } \\
\text { motif }\end{array}$ & $\begin{array}{l}\text { Influence of branching } \\
\text { on PA self-assembly }\end{array}$ & 54 \\
\hline $\begin{array}{l}\mathrm{C}_{12} \mathrm{COOH}\left(\mathrm{CH}_{2}\right)_{2} \mathrm{D}\left(\mathrm{C}_{12}\right) \mathrm{A}_{2}-\mathrm{C}_{10} \mathrm{~N}\left(\mathrm{CH}_{3}\right)^{3+} \mathrm{Br}^{-} \\
\text {Thy- } \mathrm{C}_{12} \mathrm{COOH}\left(\mathrm{CH}_{2}\right)_{2} \mathrm{D}\left(\mathrm{C}_{12}\right) \mathrm{F}_{2}-\mathrm{C}_{10} \mathrm{~N}\left(\mathrm{CH}_{3}\right)^{3+} \mathrm{Br}^{-} \\
\text {Thy denotes thymine }\end{array}$ & $\begin{array}{l}\text { de novo } \\
\text { designs }\end{array}$ & $\begin{array}{l}\text { Use of PA nanofibrils to } \\
\text { attach gold } \\
\text { nanoparticles via } \\
\text { complementary } \\
\text { interactions }\end{array}$ & 55 \\
\hline $\begin{array}{l}\mathrm{C}_{16}-\mathrm{A}_{6} \mathrm{E}_{3}, \mathrm{C}_{16^{-}} \mathrm{V}_{2} \mathrm{~A}_{2} \mathrm{E}_{2} \mathrm{G}_{2} \text { REDKETV, } \mathrm{C}_{16^{-}} \\
\mathrm{V}_{2} \mathrm{~A}_{2} \mathrm{E}_{2} \mathrm{G}_{2} \mathrm{TKRE}_{2} \mathrm{VD}, \mathrm{C}_{16^{-}} \mathrm{A}_{2} \mathrm{E}_{2} \mathrm{G}_{2} \text { REDKETV }\end{array}$ & $\begin{array}{l}\text { de novo } \\
\text { design }\end{array}$ & X-ray induced ordering & 56 \\
\hline $\mathrm{C}_{16}-\mathrm{V}_{3} \mathrm{~A}_{3} \mathrm{E}_{3}$ and others & $\begin{array}{l}\text { de novo } \\
\text { design }\end{array}$ & $\begin{array}{l}\text { Formation of aligned } \\
\text { monodomain strings }\end{array}$ & 57 \\
\hline $\mathrm{C}_{\mathrm{n}}$-KTVIIE-NH $\mathrm{NH}_{2} ; \mathrm{n}=6,8,10,12,14,16$ & $\begin{array}{l}\text { de novo } \\
\text { design }\end{array}$ & $\begin{array}{l}\text { Thermal stability as a } \\
\text { function of alkyl chain } \\
\text { length }\end{array}$ & 59 \\
\hline $\begin{array}{l}\mathrm{C}_{\mathrm{n}} \mathrm{O}-\mathrm{KTVIIE}-\mathrm{NH}\left(\mathrm{CH}_{2}\right)_{2}-(\mathrm{EO})_{68}-\mathrm{OH} ; \mathrm{n}=6,8,10 \text {, } \\
12,14 \\
\mathrm{C}_{18} \mathrm{ONHCO}\left(\text { nitrobenz)-KTVIIE-NH}\left(\mathrm{CH}_{2}\right)_{2}-\right. \\
(\mathrm{EO})_{68}-\mathrm{OH} \\
\text { EO denote ethylene oxide } \\
\text { Nitrobenz denotes a nitrobenzyl unit with linker }\end{array}$ & $\begin{array}{l}\text { de novo } \\
\text { design }\end{array}$ & $\begin{array}{l}\text { Balance between } \\
\text { hydrophobic/hydrophilic } \\
\text { self-assembly by } \\
\text { attachement of PEG. } \\
\text { UV-induced } \\
\text { disassembly }\end{array}$ & 60 \\
\hline C $_{n}$-GANPNAAG; $\mathrm{n}=6,8,10,12,14,16$ & $\begin{array}{l}\text { Derived from } \\
\text { protein of the } \\
\text { malaria } \\
\text { parasite } P \text {. } \\
\text { falciparum }\end{array}$ & $\begin{array}{l}\text { Formation of } \beta \text {-sheet } \\
\text { structure for sufficiently } \\
\text { long alkyl chain, and } \\
\text { thermal stabilization of } \\
\beta \text {-sheet }\end{array}$ & 61 \\
\hline \multirow[t]{2}{*}{$\begin{array}{l}\mathrm{C}_{24} \mathrm{CO}-\mathrm{GANPNAAG} \\
\mathrm{C}_{24} \text { chain contains diacetylene at } 4,6-10,12 \text { - or } \\
16,18 \text { - positions } \\
\text { (10,12- derivative) }\end{array}$} & \multirow[t]{2}{*}{$\begin{array}{l}\text { Derived from } \\
\text { protein of the } \\
\text { malaria } \\
\text { parasite } P \text {. } \\
\text { falciparum }\end{array}$} & $\begin{array}{l}\text { Influence of cross- } \\
\text { linking polymerization } \\
\text { of hydrophobic chains } \\
\text { on chromatic properties }\end{array}$ & 62 \\
\hline & & $\begin{array}{l}\text { Patterning using } \\
\text { polarization holography }\end{array}$ & 63 \\
\hline $\begin{array}{l}\mathrm{C}_{16}-\mathrm{G} 7 \text { with }{ }^{\mathrm{NMe}} \mathrm{G} \text { substitution in 0-6 positions, } \\
\mathrm{C}_{16}-\left(\mathrm{G}_{6} \mathrm{~A}\right) \text { ERGDS with A position varied }\end{array}$ & $\begin{array}{l}\text { de novo } \\
\text { design }\end{array}$ & $\begin{array}{l}\text { Fibril secondary } \\
\text { structure and } \beta \text {-sheet } \\
\text { packing motif }\end{array}$ & 65 \\
\hline $\begin{array}{l}\mathrm{C}_{16} \mathrm{O}-\mathrm{A}_{4} \mathrm{~K}_{4}, \mathrm{C}_{16} \mathrm{O}-\mathrm{A}_{4} \mathrm{H}_{4}, \mathrm{C}_{16} \mathrm{O}-\mathrm{A}_{4} \mathrm{E}_{4}, \mathrm{C}_{16} \mathrm{O}-\mathrm{A}_{8} \mathrm{~K}_{4}, \\
\mathrm{C}_{16} \mathrm{O}-\mathrm{A}_{12} \mathrm{~K}_{4}\end{array}$ & $\begin{array}{l}\text { de novo } \\
\text { design }\end{array}$ & $\begin{array}{l}\text { Templating of silica } \\
\text { nanotubes by PA } \\
\text { nanofibrils }\end{array}$ & 66 \\
\hline
\end{tabular}




\begin{tabular}{|c|c|c|c|}
\hline $\mathrm{C}_{8}$-KLVFFAE & $\begin{array}{l}\text { Amyloid } \beta \\
\text { peptide } \\
\text { sequence } \\
\text { A } \beta(16-22) \text {. }\end{array}$ & $\begin{array}{l}\text { Influence of lipidation } \\
\text { on } \beta \text {-sheet structure }\end{array}$ & 67 \\
\hline $\begin{array}{l}\left(\mathrm{C}_{16}\right)_{2}-\mathrm{E}-\mathrm{C}_{2}-\mathrm{X} ; \mathrm{X}=\mathrm{G}, \mathrm{A}, \mathrm{V}, \mathrm{K}, \mathrm{COOH}, \mathrm{AOEt} \\
\mathrm{AOBz}, \mathrm{IV}-\mathrm{H} 1, \mathrm{IV}-\mathrm{H} 1-\mathrm{GP}^{\mathrm{D}} \mathrm{PGP} \mathrm{P}^{\mathrm{D}} \mathrm{PPGP} \mathrm{P}^{\mathrm{D}} \mathrm{P} \\
\text { [IV-H1] = GNKGNPGWPGAP is a type IV } \\
\text { collagen sequence }\end{array}$ & $\begin{array}{l}\text { de novo } \\
\text { designs and } \\
\text { modified type } \\
\text { IV collagen } \\
\text { sequence }\end{array}$ & $\begin{array}{l}\text { Formation of } \\
\text { monolayers at the } \\
\text { air/water interface, and } \\
\text { packing within the } \\
\text { monolayer }\end{array}$ & 68 \\
\hline $\begin{array}{l}\left.\text { DOPE-(LG) })_{2} \text { DOPE-(LG) }\right)_{3} \text {, DOPE-(LG) } \\
\text { DOPE = dioleoylphosphatidyl ethanolamine }\end{array}$ & $\begin{array}{l}\text { de novo } \\
\text { design }\end{array}$ & $\begin{array}{l}\text { Ordering of } \beta \text {-sheets in } \\
\text { monolayers at the } \\
\text { air/water interface }\end{array}$ & 69 \\
\hline $\mathrm{C}_{12}-\mathrm{EVHHQKL}$ & $\begin{array}{l}\text { Amyloid } \beta \\
\text { peptide } \\
\text { sequence } \\
\text { A } \beta(11-17) \text {. }\end{array}$ & Amyloid fibrillisation & 70 \\
\hline $\begin{array}{l}\mathrm{NH}_{2}-\mathrm{SDDFGAIV}^{-\mathrm{SO}_{2-}} \\
\mathrm{N}\left(\mathrm{C}_{\mathrm{n}}\right)\left(\mathrm{CHCH}_{2} \mathrm{OH}\right) \mathrm{SCONH}_{2} \mathrm{n}=12,15,16,18\end{array}$ & $\begin{array}{l}\text { Modified } \\
\text { amylin (20- } \\
\text { 29) peptide }\end{array}$ & Fibrillisation & 71 \\
\hline $\begin{array}{l}\left(\mathrm{C}_{16}\right)_{2}-\mathrm{GC}_{2} \mathrm{G},\left(\mathrm{C}_{16}\right)_{2}-\mathrm{GC}_{2}-[\mathrm{IV}-\mathrm{H} 1]-\mathrm{Y} \\
\left(\mathrm{C}_{16}\right)_{2}-\mathrm{GC}_{2}-(\mathrm{GPHyp})_{4}-[\mathrm{IV}-\mathrm{H} 1],\left(\mathrm{C}_{14}\right)_{2}-\mathrm{GC}_{2}-[\mathrm{IV}- \\
\mathrm{H} 1]-(\mathrm{GPHyp})_{4}\end{array}$ & $\begin{array}{l}\text { Modified } \\
\text { type IV } \\
\text { collagen } \\
\text { sequence and } \\
\text { control }\end{array}$ & $\begin{array}{l}\text { Formation of triple- } \\
\text { helical structure and } \\
\text { enhanced thermal } \\
\text { stability compared to } \\
\text { unlipidated peptides }\end{array}$ & 72 \\
\hline $\begin{array}{l}\mathrm{C}_{6^{-}} \mathrm{C}_{8^{-}}, \mathrm{C}_{10^{-}}, \mathrm{C}_{12^{-}} \mathrm{C}_{14^{-}} \& \mathrm{C}_{16^{-}} \&\left(\mathrm{C}_{12}\right)_{2^{-}} \\
\text {(GPHyp) })_{4^{-}}[\mathrm{IV}-\mathrm{H} 1]-(\mathrm{GPHyp})_{4}\end{array}$ & $\begin{array}{l}\text { Modified } \\
\text { type IV } \\
\text { collagen } \\
\text { sequence }\end{array}$ & $\begin{array}{l}\text { Stabilization of polypro } \\
\text { II triple helical } \\
\text { structures }\end{array}$ & 73 \\
\hline $\begin{array}{l}\mathrm{C}_{6^{-}} \& \mathrm{C}_{16^{-}} \&\left(\mathrm{C}_{12}\right)_{2}-\mathrm{G}-\mathrm{C}_{2}-\mathrm{KA}[\mathrm{GIGALKA}]_{2} \\
\mathrm{KA}[\mathrm{GIGALKA}]_{2} \\
\mathrm{C}_{6^{-}}, \mathrm{C}_{8^{-}}, \mathrm{C}_{10^{-}}, \mathrm{C}_{12^{-}} \mathrm{C}_{14^{-}} \text {\& }_{16^{-}} \&\left(\mathrm{C}_{12}\right)_{2^{-}-\mathrm{G}^{-} \mathrm{C}_{2^{-}}} \\
{[\mathrm{GPG}]_{4}(\mathrm{GVKGNKGNPGWPGAP})[\mathrm{GPG}]_{4}}\end{array}$ & $\begin{array}{l}\text { de novo 16- } \\
\text { residue coiled } \\
\text { coil peptide } \\
\text { Collagen- } \\
\text { derived }\end{array}$ & $\begin{array}{l}\text { Influence of alkyl chain } \\
\text { on helical secondary } \\
\text { structure formation, and } \\
\text { thermal stability }\end{array}$ & 74 \\
\hline $\mathrm{C}_{16}$-WAAAAKAAAAKAAAAKA & $\begin{array}{l}\text { de novo } \\
\text { design }\end{array}$ & $\begin{array}{l}\text { Transformation from } \\
\text { spherical to wormlike } \\
\text { micelles with } \\
\text { development of } \beta \text {-sheet } \\
\text { structure }\end{array}$ & 75 \\
\hline $\begin{array}{l}\mathrm{C}_{11} \mathrm{ONH}-\mathrm{VRGDV}, \mathrm{C}_{12} \mathrm{ONH}-\mathrm{VRGDV}, \mathrm{C}_{12} \mathrm{ONH}- \\
\text { ERGDE, Fmoc-VRGDV }\end{array}$ & $\begin{array}{l}\text { RGD cell } \\
\text { adhesion } \\
\text { motif }\end{array}$ & $\begin{array}{l}\text { pH effect on self- } \\
\text { assembly }\end{array}$ & 76 \\
\hline $\begin{array}{l}\mathrm{NH} 2\left(\mathrm{CH}_{2}\right)_{4} \mathrm{CHNH}_{2} \mathrm{CO}- \\
\text { GPAALKRARNYEAARRSRARKLQRMKQLE- } \\
\text { (EIEALKA)-Ke-C } 12 \text {-MMA } \\
\text { MMA denotes methylmethacrylate }\end{array}$ & $\begin{array}{l}\text { DNA binding } \\
\text { sequence and } \\
\text { coiled-coil } \\
\text { septet }\end{array}$ & Self-assembly & 77 \\
\hline$\left(\mathrm{C}_{18}\right) \mathrm{OCO}\left(\mathrm{CH}_{2}\right)_{2} \mathrm{CH}\left(\mathrm{COOC}_{18}\right)(\beta \mathrm{A}) \mathrm{RGD}-\mathrm{COOH}$ & RGD cell & Cell spreading & 78 \\
\hline
\end{tabular}




\begin{tabular}{|c|c|c|c|}
\hline $\begin{array}{l}\left(\mathrm{C}_{18}\right) \mathrm{OCO}\left(\mathrm{CH}_{2}\right)_{2} \mathrm{CH}\left(\mathrm{COOC}_{18}\right)(\beta \mathrm{A}) \mathrm{DGR}-\mathrm{NH}_{2} \\
\left(\mathrm{C}_{18}\right) \mathrm{OCO}\left(\mathrm{CH}_{2}\right)_{2} \mathrm{CH}\left(\mathrm{COOC}_{18}\right)(\beta \mathrm{A}) \mathrm{DGR}(\beta \mathrm{A}) \\
\mathrm{CH}\left(\mathrm{COOC}_{18}\right)\left(\mathrm{CH}_{2}\right)_{2}\left(\mathrm{COOC}_{18}\right)\end{array}$ & $\begin{array}{l}\text { adhesion } \\
\text { motif }\end{array}$ & & \\
\hline 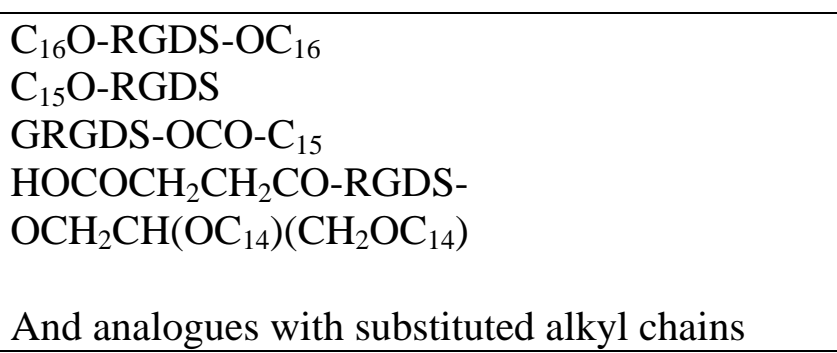 & $\begin{array}{l}\text { RGD cell } \\
\text { adhesion } \\
\text { motif }\end{array}$ & Inhibition of metastasis & 79 \\
\hline $\begin{array}{l}\mathrm{C}_{\mathrm{n}}-16 \mathrm{r}-\mathrm{Y}-\mathrm{SPARC} \mathrm{C}_{119-122} ; \mathrm{n}=6,10,14,16,18 \text {, } \\
18: 1 \text { and } 18: 1-\mathrm{OH} \\
\text { 16r denotes KAEIEALKAEIEALKA } \\
\text { SPARC }_{119-122} \text { denotes KHGK-NH } \\
\end{array}$ & $\begin{array}{l}\text { SPARC 119- } \\
122 \text { sequence } \\
\text { and 16- } \\
\text { residue coiled } \\
\text { coil sequence }\end{array}$ & $\begin{array}{l}\text { Cell adhesion and self- } \\
\text { assembly }\end{array}$ & 82 \\
\hline $\begin{array}{l}\mathrm{C}_{16} \mathrm{O}-\mathrm{NH}-\mathrm{GTAGLIGQES}-\mathrm{COOH} \\
\mathrm{C}_{16} \mathrm{O}-\mathrm{NH}-\mathrm{GTAGLIGQERGDS-COOH} \\
\mathrm{C}_{16} \mathrm{O}-\mathrm{NH}-\mathrm{GTALIGQERRDGS}\end{array}$ & $\begin{array}{l}\text { RGDS cell } \\
\text { adhesion } \\
\text { motif (or } \\
\text { scrambled } \\
\text { control) and } \\
\text { MMP } \\
\text { degradable } \\
\text { sequence }\end{array}$ & $\begin{array}{l}\text { Neural cell growth. } \\
\text { Biodegradability of PA } \\
\text { network, mechanical } \\
\text { properties of hydrogels }\end{array}$ & 83 \\
\hline \multirow[t]{2}{*}{$\mathrm{C}_{16}-\mathrm{A}_{4} \mathrm{G}_{3}$ EIKVAV } & \multirow[t]{2}{*}{$\begin{array}{l}\text { IKVAV cell } \\
\text { adhesion } \\
\text { motif }\end{array}$} & $\begin{array}{l}\text { Selective differentiation } \\
\text { of neural progenitor } \\
\text { cells }\end{array}$ & 84 \\
\hline & & $\begin{array}{l}\text { Treatment of spinal cord } \\
\text { injury }\end{array}$ & 85 \\
\hline $\begin{array}{l}\mathrm{C}_{16}-\mathrm{V}_{3} \mathrm{~A}_{3} \mathrm{~K}_{3} \mathrm{RGDS}, \mathrm{C}_{16}-\mathrm{V}_{3} \mathrm{~A}_{3} \mathrm{~K}_{3} \mathrm{DGSR} \text { and } \\
\mathrm{C}_{16}-\mathrm{V}_{3} \mathrm{~A}_{3} \mathrm{~K}_{3}, \mathrm{C}_{16}-\mathrm{V}_{3} \mathrm{~A}_{3} \mathrm{R}_{3}, \mathrm{C}_{16}-\mathrm{V}_{3} \mathrm{~A}_{3} \mathrm{E}_{3} \text { (diluents) }\end{array}$ & $\begin{array}{l}\text { RGDS cell } \\
\text { adhesion } \\
\text { motif, } \\
\text { scrambled } \\
\text { control and } \\
\text { diluent PAs }\end{array}$ & $\begin{array}{l}\text { Growth of bone marrow } \\
\text { stem and progenitor } \\
\text { cells }\end{array}$ & 86 \\
\hline $\begin{array}{l}\mathrm{HSNGLPLG}_{3} \mathrm{E}_{3} \mathrm{~A}_{3} \mathrm{~V}_{3}(\mathrm{~K})-\mathrm{COC}_{11} \mathrm{H}_{23} \\
\mathrm{C}_{16} \mathrm{O}-\mathrm{V}_{3} \mathrm{~A}_{3} \mathrm{E}_{3}\end{array}$ & $\begin{array}{l}\text { HSNGLPL } \\
\text { TGF- } \beta 1 \\
\text { domain }\end{array}$ & Cartilage regeneration & 87 \\
\hline $\mathrm{C}_{16} \mathrm{O}$-LRKKLGKA & $\begin{array}{l}\text { Heparin- } \\
\text { binding } \\
\text { sequence }\end{array}$ & Angiogenesis & 88 \\
\hline $\begin{array}{l}\text { RGDSKKLLA(K)-C } 9 \text { O-diacetylene- } \mathrm{C}_{12} \\
\text { with KKLLA(K)-C } \mathrm{C}_{9} \mathrm{O} \text {-diacetylene- } \mathrm{C}_{12} \text { as diluent }\end{array}$ & $\begin{array}{l}\text { RGDS cell } \\
\text { adhesion } \\
\text { motif }\end{array}$ & $\begin{array}{l}\text { Alignment of stem cells } \\
\text { using soft lithographic } \\
\text { photopatterning } \\
\text { methods }\end{array}$ & 89 \\
\hline $\begin{array}{l}\mathrm{C}_{16} \mathrm{O}-\mathrm{A}_{4} \mathrm{G}_{3} \mathrm{~S} \text { (Phos)RGD, } \\
\mathrm{C}_{16} \mathrm{O}-\mathrm{A}_{4} \mathrm{G}_{3} \mathrm{EIKVAV}\end{array}$ & $\begin{array}{l}\text { RGD/IKVAV } \\
\text { cell adhesion } \\
\text { motifs }\end{array}$ & $\begin{array}{l}\text { Alignment of fibrils by } \\
\text { soft lithography }\end{array}$ & 90 \\
\hline
\end{tabular}




\begin{tabular}{|c|c|c|c|}
\hline \multirow{2}{*}{$\begin{array}{l}\left(\mathrm{C}_{16}\right)_{2} \mathrm{NCICH}(\mathrm{EO})_{4} \mathrm{RGDF}(\mathrm{K}) \\
\left(\mathrm{C}_{16}\right)_{2} \mathrm{~N} \text {-chalcone-(EO) }{ }_{3} \mathrm{RGDF}(\mathrm{K}) \\
\text { EO indicates ethylene oxide, chalcone is a } \\
\text { chromophore unit employed in ref }\end{array}$} & \multirow[t]{2}{*}{$\begin{array}{l}\text { RGD cell } \\
\text { adhesion } \\
\text { motif }\end{array}$} & $\begin{array}{l}\text { RGD-functionalized } \\
\text { vesicles - adhesion to } \\
\text { endothelial cells }\end{array}$ & 81 \\
\hline & & $\begin{array}{l}\text { RGD-functionalized } \\
\text { vesicles - adhesion to } \\
\text { integrins }\end{array}$ & 80 \\
\hline \multirow[t]{2}{*}{$\mathrm{C}_{16}-\mathrm{KTTKS}$} & \multirow{2}{*}{$\begin{array}{l}\text { Matrikine } \\
\text { from } \\
\text { propeptide } \\
\alpha 1(\mathrm{I}) \\
\text { collagen }_{212-216}\end{array}$} & $\begin{array}{l}\text { Collagen production, } \\
\text { application in skincare } \\
\text { products }\end{array}$ & $91,92,95$ \\
\hline & & Self-assembly & 96 \\
\hline $\mathrm{C}_{16}$-KTTKS, $\mathrm{C}_{16}$-GHK, $\mathrm{C}_{16}$-GQPR & $\begin{array}{l}\text { Collagen- } \\
\text { stimulating } \\
\text { peptides }\end{array}$ & $\begin{array}{l}\text { LC mass spec to } \\
\text { monitor PA content in } \\
\text { anti-wrinkle cosmetics }\end{array}$ & 93 \\
\hline 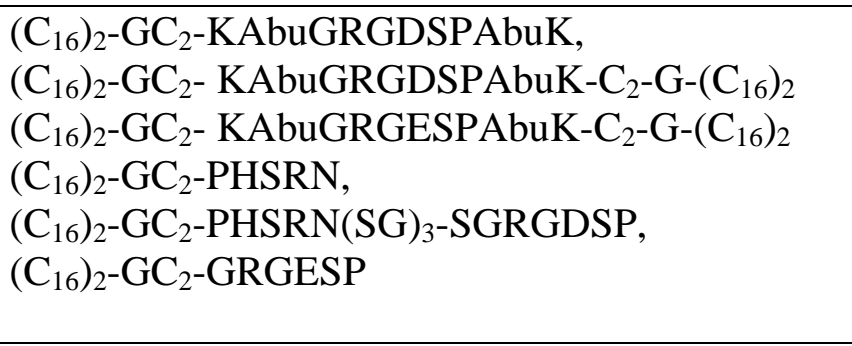 & $\begin{array}{l}\text { Contain } \\
\text { synergy } \\
\text { domain } \\
\text { PHSRN } \\
\text { and/or RGDS } \\
\text { cell adhesion } \\
\text { motif }\end{array}$ & $\begin{array}{l}\text { Interaction between PAs } \\
\text { and } \alpha 5 \beta 1 \text { integrin } \\
\text { probed by AFM }\end{array}$ & 97,98 \\
\hline $\begin{array}{l}\left(\mathrm{C}_{16}\right)_{2}-\mathrm{GC}_{2}-\mathrm{GRGDSP} \\
\left(\mathrm{C}_{16}\right)_{2}-\mathrm{GC}_{2}-\mathrm{GRGESP} \\
\left(\mathrm{C}_{16}\right)_{2}-\mathrm{GC}_{2}-\mathrm{PHSRN} \\
\left(\mathrm{C}_{16}\right)_{2}-\mathrm{GC}_{2}-\mathrm{PHSRN}(\mathrm{SG})_{4} \mathrm{RGDSP} \\
\left(\mathrm{C}_{16}\right)_{2}-\mathrm{GC}_{2}-\mathrm{KSSPHSRN}(\mathrm{SG})_{5} \mathrm{RGDSP}\end{array}$ & $\begin{array}{l}\text { Contain } \\
\text { synergy } \\
\text { domain } \\
\text { PHSRN } \\
\text { and/or } \\
\text { RGD(E)S } \\
\text { cell adhesion } \\
\text { motif }\end{array}$ & $\begin{array}{l}\text { Influence of motif and } \\
\text { linker on adhesion and } \\
\text { proliferation of HUVEC } \\
\text { cells and fibronectin } \\
\text { production }\end{array}$ & 99 \\
\hline $\begin{array}{l}\left(\mathrm{C}_{16}\right)_{2}-\mathrm{GC}_{2}-\mathrm{PHSRN}(\mathrm{SG})_{4} \mathrm{RGDSP} \\
\left(\mathrm{C}_{16}\right)_{2}-\mathrm{GC}_{2}-\mathrm{K}(\mathrm{S})_{2} \mathrm{PHSRN}(\mathrm{SG})_{5} \mathrm{RGDSP} \\
\left(\mathrm{C}_{16}\right)_{2}-\mathrm{GC}_{2}-\mathrm{K}(\mathrm{S})_{2} \mathrm{PHSRN}(\mathrm{G})_{10} \text { RGDSP } \\
\left(\mathrm{C}_{16}\right)_{2}-\mathrm{GC}_{2}-\mathrm{K}(\mathrm{S})_{2} \mathrm{PHSRN}(\mathrm{S})_{10} \mathrm{RGDSP} \\
\left(\mathrm{C}_{16}\right)_{2}-\mathrm{GC}_{2}-\mathrm{PHSRN}(\mathrm{SG})_{5} \mathrm{RGDSP} \\
\left(\mathrm{C}_{16}\right)_{2}-\mathrm{GC}_{2}-\mathrm{K}(\mathrm{S})_{5} \mathrm{PHSRN}(\mathrm{SG})_{5} \mathrm{RGDSP}\end{array}$ & $\begin{array}{l}\text { Contain } \\
\text { synergy } \\
\text { domain } \\
\text { PHSRN and } \\
\text { RGDS cell } \\
\text { adhesion } \\
\text { motif } \\
\end{array}$ & $\begin{array}{l}\text { Influence of linker on } \\
\text { adhesion between PAs } \\
\text { and } \alpha 5 \beta 1 \text { integrin } \\
\text { probed by AFM }\end{array}$ & 100 \\
\hline $\mathrm{C}_{16}-(\mathrm{G})_{3}(\mathrm{~S})_{2} \mathrm{PHSRN}(\mathrm{SG})_{5} \mathrm{RGDSP}$ & $\begin{array}{l}\text { Contains } \\
\text { synergy } \\
\text { domain } \\
\text { PHSRN and } \\
\text { RGDS cell } \\
\text { adhesion } \\
\text { motif } \\
\end{array}$ & $\begin{array}{l}\text { Nanofibril formation, } \\
\text { hydrogelation and } \\
\text { growth/proliferation of } \\
\text { HUVEC cells }\end{array}$ & 101 \\
\hline $\begin{array}{l}\mathrm{C}_{16} \mathrm{OWG}\left[\left(\mathrm{CH}_{2}\right)_{4} \mathrm{NHCOC}_{15}\right] \mathrm{G}(\mathrm{LRKLRKRLLR})_{2}- \\
\mathrm{NH}_{2}\end{array}$ & $\begin{array}{l}\text { Binding sites } \\
\text { for LDL } \\
\text { receptor and } \\
\text { proteoglycans }\end{array}$ & $\begin{array}{l}\text { Internalization within } \\
\text { cells }\end{array}$ & 102 \\
\hline $\begin{array}{l}\mathrm{C}_{16} \text {-LSQETFSDLWKLLPEN } \\
\text { and } \\
\mathrm{C}_{16} \text {-K(rho)LSQETFSDLWKLLPEN }\end{array}$ & $\begin{array}{l}\text { P53 tumor } \\
\text { suppressor } \\
\text { protein }\end{array}$ & $\begin{array}{l}\text { Mechanism of } \\
\text { internalization in cells }\end{array}$ & 103 \\
\hline
\end{tabular}




\begin{tabular}{|c|c|c|c|}
\hline rho denotes a rhodamine derivative & $\begin{array}{l}\text { sequence } \\
\text { p53 } 14-29\end{array}$ & & \\
\hline $\mathrm{C}_{16} \mathrm{ONH}-\mathrm{GTAGLIGQRGDS-COOH}$ & $\begin{array}{l}\text { Contains } \\
\text { MMP-2 } \\
\text { sensitive (and } \\
\text { RGDS- } \\
\text { containing) } \\
\text { sequence }\end{array}$ & $\begin{array}{l}\text { Enzymatic release of } \\
\text { cisplatin from hydrogel }\end{array}$ & 108 \\
\hline $\begin{array}{l}\text { DOPE-PEG }{ }_{12}-\mathrm{G}(\mathrm{EIAALEK})_{3}-\mathrm{NH}_{2}, \\
\text { DOPE-PEG }_{12}-\mathrm{G}(\mathrm{KIAALEK})_{3} \mathrm{GW}-\mathrm{NH}_{2}\end{array}$ & $\begin{array}{l}\text { SNARE } \\
\text { protein } \\
\text { mimics }\end{array}$ & $\begin{array}{l}\text { Membrane fusion } \\
\text { induced by } \\
\text { complementary coiled } \\
\text { coil peptides }\end{array}$ & 109 \\
\hline $\begin{array}{l}\mathrm{C}_{12} \mathrm{O}-Y \text { YAAKKAAKAAKKAAKAA } \\
\mathrm{C}_{12} \mathrm{O}-\text { YGAKAKAAKAAKAKAAKA } \\
\mathrm{C}_{12} \mathrm{O}-\mathrm{KLFKRHLKWKII}\end{array}$ & $\begin{array}{l}\text { Cationic } \\
\text { peptides - } \\
\text { two designed } \\
\text { and one } \\
\text { biomimetic }\end{array}$ & $\begin{array}{l}\text { Antimicrobial activity } \\
\text { and eukaryotic cell } \\
\text { toxicity }\end{array}$ & 110 \\
\hline $\begin{array}{l}\mathrm{C}_{16}-\mathrm{KAK}, \mathrm{C}_{16}-\mathrm{KGK}, \mathrm{C}_{16}-\mathrm{KKK}, \mathrm{G}_{16}-\mathrm{K}\left({ }^{\mathrm{D}} \mathrm{K}\right) \mathrm{K}, \mathrm{C}_{16^{-}} \\
\mathrm{KLK}, \mathrm{C}_{16}-\mathrm{K}\left({ }^{\mathrm{D}} \mathrm{K}\right), \mathrm{C}_{16}-\mathrm{K}\end{array}$ & $\begin{array}{l}\text { de novo } \\
\text { design }\end{array}$ & Antimicrobial properties & 111 \\
\hline $\begin{array}{l}\mathrm{C}_{\mathrm{n}} \mathrm{O}-\mathrm{GCKPTFRRLKWKTKCG-NH} \\
\mathrm{C}_{16} \mathrm{O}-\mathrm{IKISGKWKAQKRFLKM} \\
\mathrm{C}_{16} \mathrm{O}-\mathrm{Q} A L N Y E I R G Y V I I K P \\
\text { Underline denotes a cylic peptide (linked through } \\
\text { cysteine S-S) }\end{array}$ & $\begin{array}{l}\text { LPS-binding } \\
\text { peptides }\end{array}$ & $\begin{array}{l}\text { LPS-neutralizing } \\
\text { activity and self- } \\
\text { assembly }\end{array}$ & 114 \\
\hline $\mathrm{C}_{16}-\mathrm{C}_{4} \mathrm{G}_{3} \mathrm{~S}$ (Phos)RGD & $\begin{array}{l}\text { RGD cell } \\
\text { adhesion } \\
\text { motif }\end{array}$ & $\begin{array}{l}\text { Nanofibril formation } \\
\text { and templating of } \\
\text { artificial bone } \\
\text { mineralization }\end{array}$ & 115 \\
\hline $\begin{array}{l}\mathrm{C}_{16}-(\mathrm{SV})_{2} \mathrm{G}_{3} \mathrm{~S}(\text { Phos)RGD } \\
\text { S(Phos) denotes phosphorylated serine }\end{array}$ & $\begin{array}{l}\text { RGD cell } \\
\text { adhesion } \\
\text { motif }\end{array}$ & $\begin{array}{l}\text { Templating of artificial } \\
\text { bone mineralization }\end{array}$ & 116 \\
\hline DOPE-(LG) 4 & $\begin{array}{l}\text { de novo } \\
\text { design }\end{array}$ & $\begin{array}{l}\text { Biomimetic } \\
\text { mineralization of } \mathrm{CaCO}_{3}\end{array}$ & 117 \\
\hline $\begin{array}{l}{\left[\mathrm{C}_{15} \mathrm{COO}\left(\mathrm{CH}_{2}\right)\right]_{2} \mathrm{CHPO}_{4}^{-}-} \\
\left(\mathrm{CH}_{2}\right)_{2} \mathrm{NHCO}\left(\mathrm{CH}_{2}\right)_{2} \mathrm{CO}-[\mathrm{HR} 1(\mathrm{~A} 153-\mathrm{Q} 202] \\
\text { The peptide contains a sequence from heptad } \\
\text { repeat region } 1(\mathrm{HR} 1) \text { from the } \mathrm{F}_{1} \text { glycoprotein of } \\
\text { respiratory syncytial virus }\end{array}$ & $\begin{array}{l}\text { HR1 } \\
\text { sequence }\end{array}$ & $\begin{array}{l}\text { Synthetic virus-like } \\
\text { particle stimulating } \\
\text { antibody production }\end{array}$ & 122 \\
\hline $\begin{array}{l}\text { Ac- } \\
\text { A(Ox)AEAAEKAAKYAAEAAEKAAKA(Ox)A- } \\
\text { NH2 } \\
\text { Ox denotes ornithine or ornithine- } \mathrm{C}_{n}, \mathrm{n}=12,14 \text {, } \\
16,18,20\end{array}$ & $\begin{array}{l}\text { de novo } \\
\text { design }\end{array}$ & Denaturing agents & 123 \\
\hline $\begin{array}{l}\left.\left(\mathrm{C}_{18}\right)_{2} \mathrm{AhOH} \text {-Lys(DTPAGlu)-(AhOH }\right)_{2} \text {-octreotide } \\
\left.\left(\mathrm{C}_{18}\right)_{2} \mathrm{AhOH} \text {-Lys(DOTA)-(AhOH) }\right)_{2} \text {-octreotide } \\
\text { AhOH }=4,7,10,13,16,-19 \text {-hexaoxaheneicosanoic } \\
\text { acid }\end{array}$ & $\begin{array}{l}\text { Octreotide } \\
\text { peptide }\end{array}$ & $\begin{array}{l}\text { MRI contrast agents for } \\
\text { cancer detection }\end{array}$ & 124 \\
\hline
\end{tabular}




\begin{tabular}{|c|c|c|c|}
\hline $\begin{array}{l}\text { DOTA and DTPAGlu denote chelating agents } \\
\text { Octreotide }={ }^{D} \text { FCF }^{\mathrm{D}} \text { WKTCT }(\text { ol }) \text { underline } \\
\text { denotes cyclic peptide }\end{array}$ & & & \\
\hline $\begin{array}{l}\mathrm{D} \beta \mathrm{A}(\mathrm{K}-\beta \mathrm{ADCOOH}) \mathrm{L}_{2} \mathrm{C}_{4}(\mathrm{~K}) \mathrm{OC}_{16} \\
\mathrm{~K}\left(\mathrm{~K}-\mathrm{KNH}_{2}\right) \mathrm{L}_{2} \mathrm{C}_{4}(\mathrm{~K}) \mathrm{OC}_{16} \\
\mathrm{D} \beta \mathrm{A}(\mathrm{K}-\mathrm{DSDGR}) \mathrm{L}_{3} \mathrm{~A}_{3}(\mathrm{~K}) \mathrm{OC}_{16} \\
\beta \mathrm{A} \text { denotes } \beta \text {-alanine }\end{array}$ & $\begin{array}{l}\text { de novo } \\
\text { branched } \\
\text { designs, and } \\
\text { incorporation } \\
\text { of RGD cell } \\
\text { adhesion } \\
\text { motif }\end{array}$ & $\begin{array}{l}\text { Encapsulation of carbon } \\
\text { nanotubes }\end{array}$ & 125 \\
\hline $\begin{array}{l}\text { Biotin-RGDSKG }{ }_{3} \mathrm{~A}_{3}(\mathrm{~K}) \mathrm{OC}_{16} \\
\text { K(K-Biotin-RGDS)X } \mathrm{X}_{3} \mathrm{~A}_{3}(\mathrm{~K}) \mathrm{OC}_{16} \\
(\mathrm{~K}-\text { Biotin-RGDS })\left(\mathrm{K}-\mathrm{Biotin}_{\mathrm{R}} \mathrm{R} \text {-RS }\right) \mathrm{X}_{3} \mathrm{~A}_{3}(\mathrm{~K}) \mathrm{OC}_{16} \\
\mathrm{X}=\mathrm{G} \text { or } \mathrm{VCH}_{3}\end{array}$ & $\begin{array}{l}\text { de novo } \\
\text { branched } \\
\text { designs } \\
\text { incorporating } \\
\text { RGDS and } \\
\text { biotin }\end{array}$ & $\begin{array}{l}\text { Presentation of biotin on } \\
\text { PA nanofibrils }\end{array}$ & 126 \\
\hline $\mathrm{C}_{\mathrm{n}}$-KTVIIE; $\mathrm{n}=6,8,10,12,14,16$ & $\begin{array}{l}\text { Model } \\
\text { amyloid } \\
\text { forming } \\
\text { peptide }\end{array}$ & $\begin{array}{l}\text { Stabilization of } \beta \text {-sheet } \\
\text { structure }\end{array}$ & 129 \\
\hline
\end{tabular}

* The difference between $\mathrm{C}_{\mathrm{n}}$ labelling of alkyl chain and $\mathrm{C}$ denoting cysteine within a peptide sequence should be evident from the structure 


\section{Figures}



Fig.1. Proposed mechanism for nanotube formation by $V_{6} D$, via the formation of peptide bilayers. ${ }^{15}$ Peptides may form a closed ring based on a bilayer structure. The closed rings may stack to form a nanotube. Nanotubes were observed to be connected via a three-way junction, a model for which is shown. 
(a)

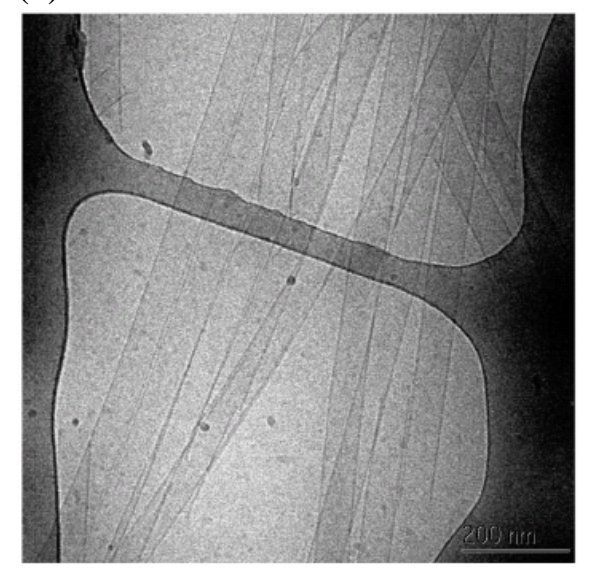

(b)



Fig.2. $\mathrm{A}_{6} \mathrm{~K}$ nanotubes. (a) cryo-TEM image ${ }^{28}$ and (b) model for nanotube structure. ${ }^{29}$ 


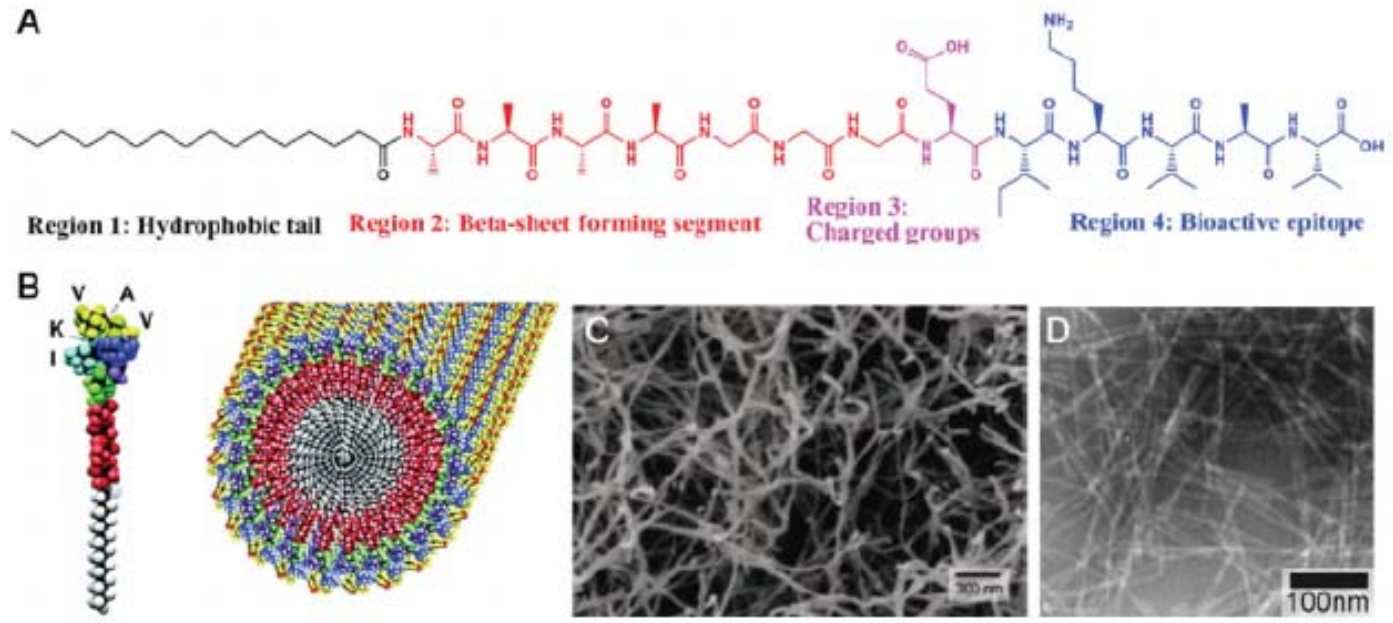

Fig.3. (a) Molecular structure of a typical PA studied by the Stupp group, incorporating motifs as indicated (the bioactive epitope in this case is the laminin IKVAV sequence), (b) Diagram of nanofibril structure, (c) SEM image of nanofibril network in DMEM cell medium (d) TEM image. ${ }^{5}$ 


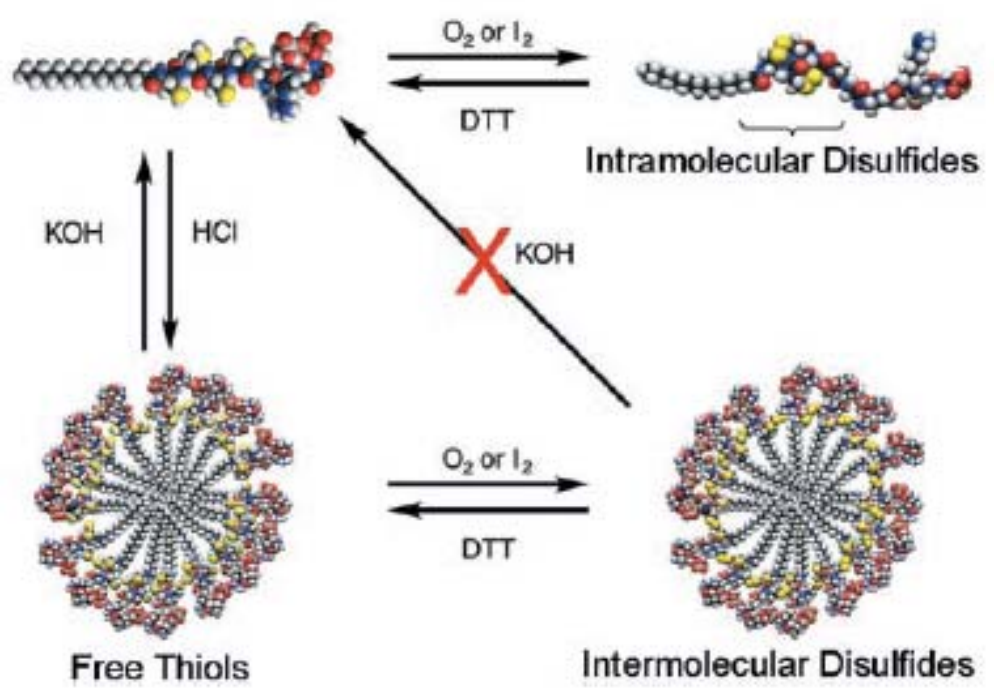

Fig.4. Schematic showing reversible $\mathrm{pH}$-induced self-assembly and covalent capture of PAs containing $\mathrm{C}_{4}$ domains. ${ }^{43}$ Molecules self-assemble upon acidification and disassemble at neutral and basic $\mathrm{pH}$ when fully reduced. Oxidized molecules will not self-assemble at acidic $\mathrm{pH}$, an observation ascribed to the distorted conformation required by intramolecular disulfide bonds. Oxidised fibrils lose their $\mathrm{pH}$ sensitivity and therefore exhibit enhanced stability. 

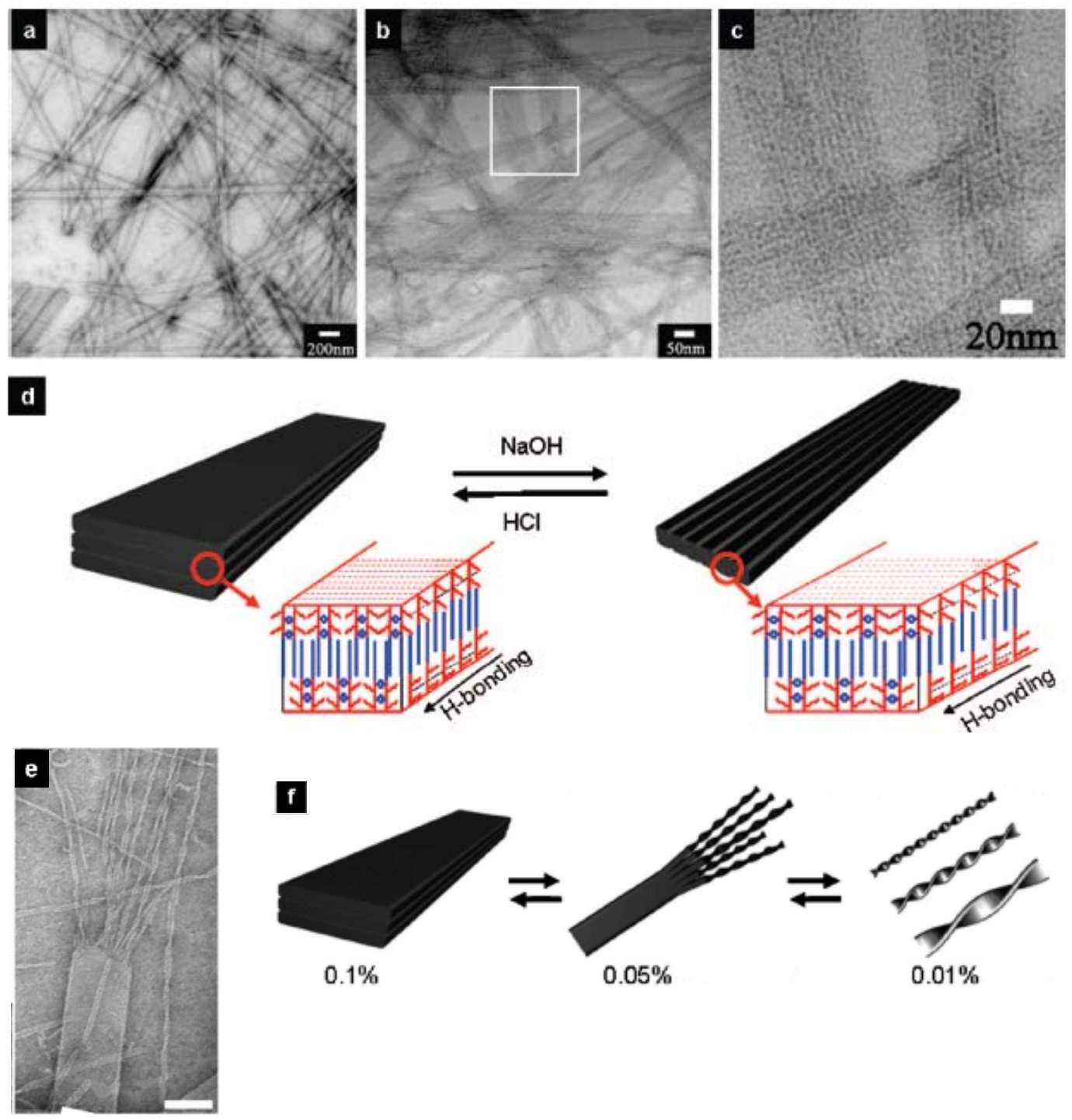

Fig.5. (a) TEM image of nanobelts formed by $\mathrm{C}_{16} \mathrm{O}-\mathrm{VEVE}$, (b) Grooved nanobelts form upon increasing $\mathrm{pH}$, (c) Higher magnification image of grooved nanobelts, (d) Schematic of morphology transition (e) Formation of twisted nanoribbons at the end of a nanobelt, (f) Proposed mechanism of unravelling of tapes on dilution. ${ }^{52}$ 
(a)

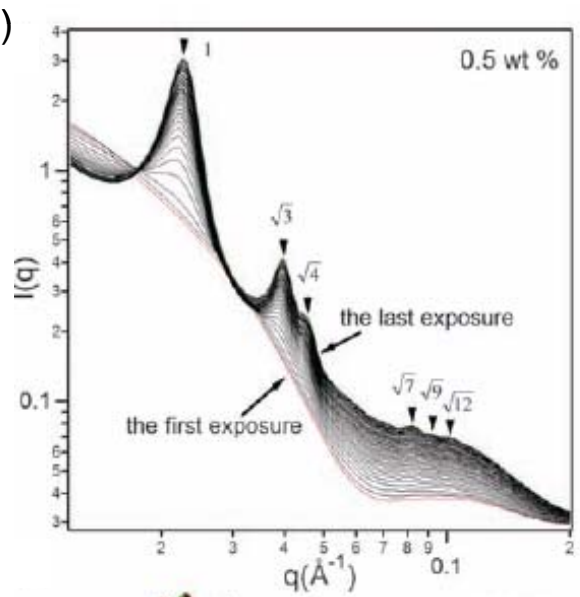

(b)

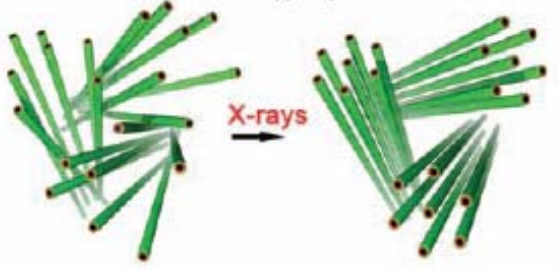

Fig.6. Exposure to synchrotron $\mathrm{X}$-rays induces a transition from isotropic- hexagonal order for an $0.5 \mathrm{wt} \%$ solution of PA $\mathrm{C}_{16}-\mathrm{A}_{6} \mathrm{E} 3{ }^{56}$ (a) SAXS data, (b) Schematic of ordering of PA fibril bundles. 

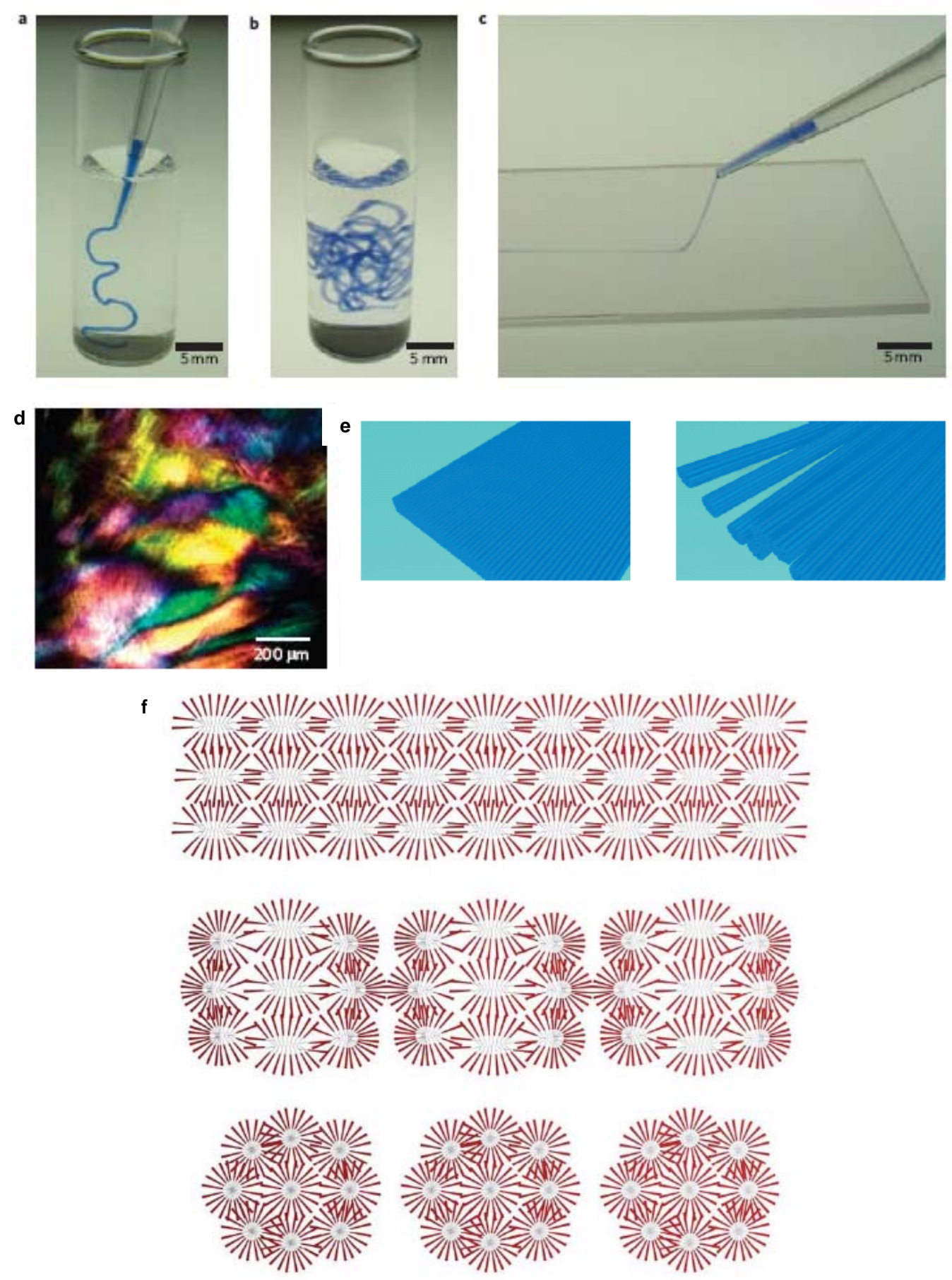

Fig.7. (a,b) Noodle-like strings of PA solution (stained with trypan blue) injected into phosphate-buffered saline, (c) The same solution dragged through a thin film of aqueous $\mathrm{CaCl}_{2}$, (d) Birefringent texture of a gel, (e) Model for plaque, rupturing into a bundle of fibrils, (f) Side view of model of break-up of lamellar plaque into fibrillar bundles upon cooling. ${ }^{57}$ 
(a)

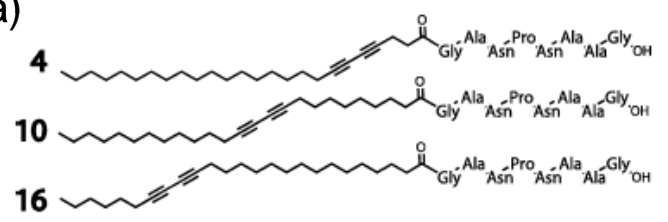

(b)



Fig.8. (a) Diacetylene-containing PAs studied by van den Heuvel et al. ${ }^{62}$, (b) Spatially selective polymerization, depending on polarization direction of UV (shown). ${ }^{63}$ Darker lines indicate more strongly polymerized fibrils. 


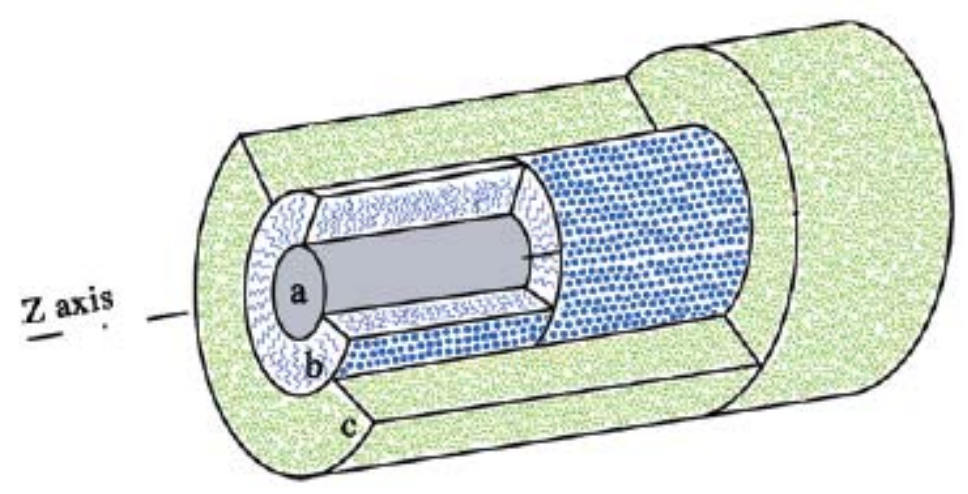

Fig.9. Model of PA fibril structure showing a lipid core, $\mathbf{b} \beta$-sheet region stabilized by H-bonding between four residues, $\mathbf{c}$ Peripheral peptide region. ${ }^{65}$ 

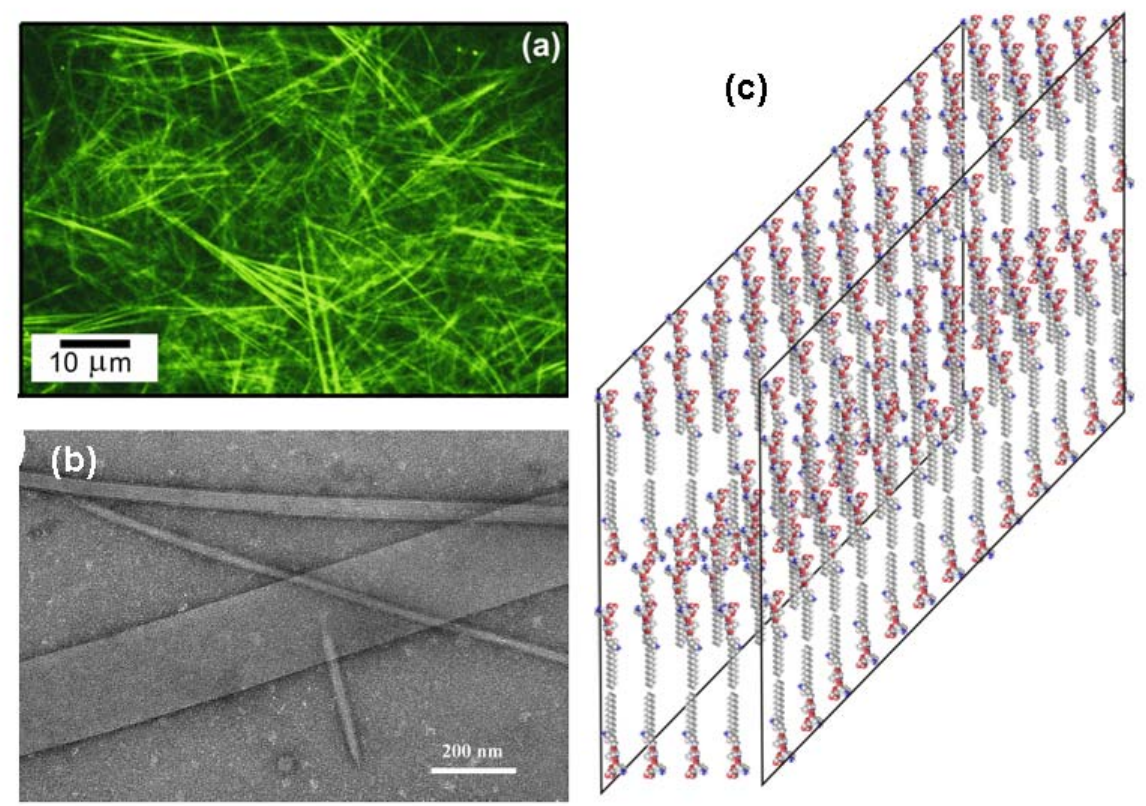

Fig.10. Nanostructure of Matrixyl. ${ }^{130}$ (a) Confocal microscopy image showing fibrillar superstructure extending to near macroscopic scale, (b) Negative stain TEM image showing detail of tape-like structure of fibrils at the nanoscale, (c) Model for ordering of PA layers perpendicular to tape surface, deduced from SAXS data. 




Fig.11. Fluorescence microscopy images of live SJSA-1 cells showing (a) internalization of PA via rhodamine fluorescence (red), (b) non-PA peptide control showing absence of internalization. Nuclei are stained by Hoechst 33342 (blue). ${ }^{103}$ 
(A)

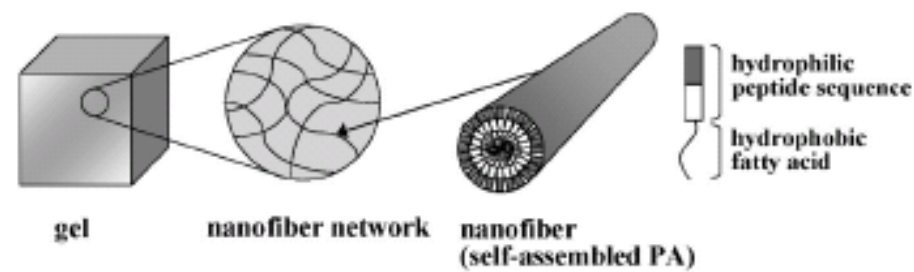

(B)



(4)

Fig.12. Concept of PA-based hydrogel for the bioresponsive release of cisplatin. ${ }^{108}$ (a) Scheme of nanofibrillar network structure within hydrogel, (b) Mechanism of crosslinking of (1)-(1)-(3) aspartic acid residues or (2)-(4) carboxyl termini. 


\section{TOC Entry}

The self-assembly of amphiphilic peptides and peptide amphiphiles is reviewed.



